\title{
ANALISIS PERTUMBUHAN DAN ELASTISITAS PENDAPATAN ASLI DAERAH (PAD) TERHADAP PRODUCT DOMESTIC REGIONAL BRUTTO (PDRB) DI KABUPATEN LOMBOK TIMUR TAHUN 2016-2019
}

\author{
Siti Fatimah, Tuty Handayani.
}

Universitas Mataram

\begin{tabular}{l}
\hline A R T I C LE I N F O \\
\hline Keywords: \\
PAD, GDRP, Current Price, \\
Constant Price
\end{tabular}

Kata Kunci:

PAD, PDRB, Atas Dasar

Harga Berlaku, Atas Dasar

Harga Konstan
ABSTRACT: This descriptive study, located in East Lombok Regency, aims to determine the growth, shape, and magnitude of the elasticity of Regional Original Income (PAD) related to the growth rate of the Gross Domestic Regional Product (GDRP) of East Lombok Regency from 2016-2019.

The results showed that; a) The rate of development of Regional Original Income (PAD) to Gross Domestic Regional Product (GDRP) at Current Prices East Lombok Regency in 2016-2019 is as follows: In 2016 the growth was 9.75 percent, in 2017 it increased slightly to Rp. 10.62 percent, in 2018 it decreased to 10.33 percent, in 2019 it was 10.47 percent. The highest growth rate occurred in 2017 which was 10.62 percent. The average growth rate for 4 (four) years from 2016-2019 reached 10.29 percent; b) The rate of development of Regional Original Income (PAD) to Gross Domestic Regional Product (GDRP) at Constant Prices in 2010 in East Lombok Regency in 2016-2019 is as follows: In 2016 its contribution growth was 10.04 percent, in 2017 it increased to 10.53 percent, in 2018 it increased to 11.06 percent, in 2019 it increased again to 11.21 percent. The highest growth rate occurred in 2019 which was 13.95 percent. The average growth rate for 4 (four) years from 2016-2019 reached 11.36 percent; c) The contribution of the balancing fund to the regional income of East Lombok Regency is very influential so that its impact on the economic growth rate is reflected the growth of GDRP at Current Price and Constant Price of East Lombok Regency for 4 (four) Years (2016-2019) is relatively very significant; and d) The elasticity of PAD to GDRP both on the basis of Current Prices and on the basis of Constant Prices in 2010 on average over the last 4 (four) years shows a positive or elastic trend. This means that if PAD increases by one unit (\%), then GDRP will increase by more than one unit (\%).

ABSTRAK: Penelitian deskriptif yang berlokasi di Kabupaten Lombok Timur ini bertujuan untuk mengetahui pertumbuhan, bentuk, dan besaran elastisitas Pendapatan Asli Daerah (PAD) yang berkaitan dengan laju pertumbuhan Product Domestic Regional Bruto (PDRB) Kabupaten Lombok Timur sejak 2016-2019.

Hasil penelitian menunjukkan bahwa; a) Laju perkembangan Pendapatan Asli Daerah (PAD) terhadap Product Domestic Regional Brutto (PDRB) Atas Dasar Harga Berlaku (ADHB) Kabupaten Lombok Timur Tahun 2016- 2019 sebagai berikut: Tahun 2016 pertumbuhannya sebesar 9,75 persen, tahun 2017 meningkat tipis menjadi sebesar 10,62 persen, tahun 2018 turun menjadi sebesar 10,33 persen, tahun 2019 menjadi sebesar 10,47 persen. Angka pertumbuhan tertinggi terjadi pada tahun 2017 yaitu sebesar 10,62 persen. Angka pertumbuhan rata-rata selama 4 (empat) tahun terhitung sejak tahun 2016-2019 mencapai 10,29 persen; b) Laju perkembangan Pendapatan Asli Daerah (PAD) terhadap Product Domestic Regional Brutto (PDRB) Atas Dasar Harga Konstan Tahun 2010 di Kabupaten Lombok Timur Tahun 2016-2019 sebagai berikut: Tahun 2016 pertumbuhan kontribusinya sebesar 10,04 persen, tahun 2017 meningkat menjadi sebesar 10,53 persen, tahun 2018 meningkat menjadi sebesar 11,06 persen, tahun 2019 meningkat lagi menjadi sebesar 11,21 persen. Angka pertumbuhan tertinggi terjadi pada tahun 2019 yaitu sebesar 13,95 persen. Angka pertumbuhan rata-rata selama 4 (empat) tahun terhitung sejak tahun 20162019 mencapai 11,36 persen; c) Kontribusi dana perimbangan terhadap pendapatan 


\begin{tabular}{l|l}
\hline & $\begin{array}{l}\text { daerah Kabupaten Lombok Timur sangat berpengaruh sehingga dampaknya terhadap } \\
\text { laju pertumbuhan ekonomi yang dicerminkan dalam pertumbuhan PDRB (ADHB) } \\
\text { maupun ADHK Kabupaten Lombok Timur selama 4 (empat) Tahun (2016-2019) relatif } \\
\text { sangat signifikan; dan d) Elastisitas PAD terhadap PDRB baik Atas Dasar Harga Berlaku } \\
\text { maupun Atas Dasar Harga Konstan tahun 2010 secara rata-rata selama 4 (empat) } \\
\text { tahun terakhir menunjukkan tren yang posisifatau Elastis. Artinya bahwa jika PAD naik } \\
\text { satu satuan (\%), maka PDRB akan mengalami kenaikan lebih dari satu satuan (\%). }\end{array}$ \\
\hline Corresponding Author : \\
Alamat : Program Studi Ekonomi Pembangunan, Fakultas Ekonomi dan Bisnis, Universitas Mataram, Jln. Majapahit \\
No.62 Mataram. \\
e-mail: sifa25023@gmail.com
\end{tabular}

2021, EKONOBIS All right reserved 


\section{PENDAHULUAN}

Latar Belakang

Salah satu indikator untuk melihat perkembangan ekonomi suatu daerah melalui konsep Product Domestic Regional Brutto (PDRB). Secara konsepsional PDRB merupakan hasil penjumlahan nilai tambah brutto berupa produk barang dan jasa yang dihasilkan oleh seluruh unit-unit produksi di dalam batas wilayah suatu daerah atau region tertentu selama satu tahun. Dilihat dari sudut penggolongan PDRB dapat dilihat atas dasar harga berlaku yang menggambarkan nilai tambah barang dan jasa yang dihitung dengan menggunakan harga pada setiap tahun, sedangkan PDRB atas dasar harga konstan menunjukkan nilai tambah barang dan jasa yang dihitung dengan menggunakan harga pada satu tahun tertentu sebagai tahun dasar perhitungannya.

Dilihat dari segi kemanfaatannya PDRB atas dasar harga berlaku dapat digunakan untuk melihat pergeseran struktur ekonomi, sedangkan dari segi harga konstan dapat digunakan untuk mengetahui pertumbuhan ekonomi dari tahun ke tahun. Dengan demikian PDRB merupakan indikator untuk mengetahui sampai sejauh mana keberhasilan pemerintah dalam memanfaatkan sumberdaya yang ada yang dapat digunakan sebagai bahan perencanaan dan pengambilan keputusan.

Jika diamati secara time series sejak Tahun 2016-2019 pertumbuhan PDRB Kabupaten Lombok Timur menunjukkan angka pertumbuhan yang fluktuatif. Kondisi ini mengilustrasikan kepada kita bahwa fluktuasi pertumbuhan ini menginformasikan kepada kita mengenai dinamika pertumbuhan masing-masing sektor ekonomi setiap tahunnya. Dinamika ini sekaligus merupakan kondisi riil tentang pertumbuhan sektor ekonomi serta pergeseran struktur antar sektor ekonomi. Secara konseptional jika dilihat dari sembilan sektor ekonomi yang ada dapat digolongkan menjadi tiga sektor utama yang meliputi sektor primer, sektor skunder dan sektor tersier.

Nampak selama lima tahun terakhir baik pertumbuhan maupun pergeseran struktur ini telah menunjukkan kedinamisan yang cukup menggembirakan. Namun dinamika pertumbuhan di atas apakah menunjukkan adanya pergeseran struktur ekonomi ataukah tidak, sehingga diperlukan analisa serta kajian yang lebih mendalam.

Ditinjau dari sudut elastisitas, sudah barang tentu juga akan mengalami 
perubahan setiap tahunnya seiiring dengan laju pertumbuhan PDRB. Namun perubahan dimaksud apakah telah membawa pengaruh terhadap laju pertumbuhan variabel-variabel pembentuk PDRB dimaksud. Ini juga diperlukan kajian yang lebih komprehensif sebagai landasan berpijak para perencana dalam mengalokasikan dana-dana APBD yang diharapkan lebih berorientasi pada pelayanan sektor publik. Sedangkan jika diamati secara konsepsional bahwa elastisitas pertumbuhan PDRB menggambarkan tentang derajat kepekaan atau respon perubahan PDRB terhadap faktor yang mempengaruhinya seperti pertumbuhan antar sektor ekonomi. Fluktuasi pertumbuhan sektor ekonomi akan berdampak secara simultan terhadap besar kecilnya elastisitas PDRB. Semakin besar turun naikknya elastisitas sekaligus akan menunjukkan tingkat elastisitas pertumbuhan PDRB, apakah bersifat elastis, unitary atau inelastis.

Dari paparan di atas diharapkan analisis dimaksud nantinya akan memberikan informasi kepada kita tentang bagaimana pertumbuhan dan elastisitas PDRB yang dikaitkan pergeseran struktur ekonomi di wilayah Kabupaten Lombok Timur sejak Tahun 2016-2019.

\section{Rumusan Masalah}

1. Bagaimana pertumbuhan Pendapatan Asli Daerah (PAD) kaitannya dengan laju pertumbuhan Product Domestic Regional Brutto (PDRB) Kabupaten Lombok Timur dan sejak 2016-2019.

2. Bagaimana bentuk dan besaran Elastisitas Pendapatan Asli Daerah PAD kaitannya terhadap laju pertumbuhan Product Domestic Regional Brutto PDRB Kabupaten Lombok Timur sejak 2016-2019.

\section{Tujuan Penelitian}

1. Pertumbuhan Pendapatan Asli Daerah (PAD) kaitannya dengan laju pertumbuhan Product Domestic Regional Brutto (PDRB) Kabupaten Lombok Timur dan sejak 2016-2019.

2. Bentuk dan besaran Elastisitas Pendapatan Asli Daerah PAD kaitannya terhadap laju pertumbuhan Product Domestic Regional Brutto PDRB Kabupaten Lombok Timur sejak 20162019.

\section{KAJIAN PUSTAKA}

\section{Landasan Teori}

\section{Kinerja Keuangan Daerah}

Menurut Nizarwan dalam Halim (2004: 70) dalam bukunya yang berjudul Bunga Rampai Manajemen Keuangan Daerah mengatakan Kebijakan umum pengelolaan keuangan daerah disesuaikan dengan 
situasi dan kondisi serta potensi daerah dengan berpedoman pada Undangundang Nomor: 32 Tahun 2004 dan Undang-undang Nomor: 33 tahun 2004. Kesimpulannya adalah Kebijakan pengelolaan keuangan daerah dalam mengalokasikan belanja aparatur dan belanja pelayanan publik senantiasa berpegang pada prinsip anggaran berimbang dan dinamis serta efisien dan efektif dalam meningkatkan produktivitas Menurut Mardiasmo (2004) dalam bukunya yang berjudul Otonomi dan Manajemen Keuangan Daerah mengatakan Anggaran merupakan pernyataan mengenai estimasi kinerja yang hendak dicapai selama priode waktu tertentu yang dinyatakan dalamukuran finansial dan berisi rencana kegiatan yang direpresentasikan dalam bentuk rencana perolehan pendapatan dan belanja dalam satuan moneter.

Menurut Indra Bastian (2001: 6) dalam bukunya yang berjudul Manual Akuntansi Keuangan Pemerintah Daerah mengatakan bahwa penyusunan APBD adalah suatu hal yang sangat penting dalam rangka penyelenggaraan fungsi daerah otonom yang bertujuan untuk: menentukan jumlah pajak yang akan dibebankan kepada masyarakat, suatu sarana untuk mewujudkan otonomi yang nyata dan bertanggung jawab, memberi isi dan arti dari pemerintah pusat ke pemerintah daerah, sarana untuk pengawasan dan pemberian kuasa kepala daerah untuk penyelenggaraan keuangan daerah.

Selanjutnya menurut Hasbullah (2006: 4) Kinerja Keuangan Daerah merupakan suatu instrumen untuk mencermati kemampuan suatu daerah dalam aspek finansial untuk mengorganisir Anggararan Pendapatan dan Belanja Daerah (APBD) guna pencapaian visi dan misi pembangunan daerah guna peningkatan kesejahtraan masyarakat. Secara parsial dikatakan kinerja dapat diartikan sebagai alat ukur kemampuan suatu daerah dalam menggali unsur-unsur penerimaan baik penerimaan aparatur maupun penerimaan publik dalam APBD (Anggaran Pendapatan dan Belanja Daerah) untuk selanjutnya dipergunakan sebagai belanja aparatur dan belanja publik sesuai dengan kebutuhan masyarakat.

\section{Pengelolaan Keuangan Daerah}

Pengelolaan keuangan daerah tidak terlepas dari pembahasan Anggaran Pendapatan dan Belanja Daerah (APBD). Oleh sebab itu pembahasan mengenai analisis kemampuan keuangan daerah disini bertitik tolak dari pembahasan Anggaran Pendapatan dan Belanja Daerah, 
yang merupakan program kerja suatu daerah dalam bentuk angka-angka Dalam Peraturan Pemerintah Nomor 58 Tahun 2005 pengganti Peraturan Pemerintah Nomor 105 Tahun 2000 memberikan definisi Pengelolaan Keuangan Daerah adalah keseluruhan kegiatan yang meliputi perencanaan, pelaksanaan, penatausahaan, pelaporan, pertanggungjawaban, dan pengawasan keuangan daerah. Sedangkan Undangundang Nomor 17 Tahun 2003 tentang Keuangan Negara bahwa pendapatan daerah dan belanja daerah yang merupakan bagian dari keuangan negara harus dikelola secara tertib, taat pada peraturan perundang-undangan, efisien, ekonomis, efektif, transparan, dan bertanggungjawab dengan memperhatikan rasa keadilan dan kepatuhan.

Menurut Jaya dalam Munir, Djuanda, Tangkilisan (2004: 6) Keuangan Daerah adalah seluruh tatanan, perangkat kelembagaan dan kebijaksanaan anggaran daerah yang meliputi pendapatan dan belanja daerah, sedangkan menurut Peraturan Pemerintah Nomor 105 Tahun 2000 menjelaskan Keuangan Daerah adalah semua hak dan kewajiban daerah dalam rangka penyelenggaraan pemerintahan daerah yang dapat dinilai dengan uang termasuk didalamnya segala bentuk kekayaan yang berhubungan dengan hak dan kewajiban daerah tersebut, dalam kerangka Anggaran Pendapatan dan Belanja Daerah (APBD).

Menurut Bastian (2001:8) adanya hubungan yang erat antara Keuangan Negara dan Keuangan Daerah yang merupakan dasar pengelolaan keuangan daerah. Sehingga baik dalam penyusunan APBD dan pelaporan keuangan daerah maupun pelaksanaannya, menceminkan pelaksanaan otonomi daerah yang nyata dan bertanggungjawab yang mencakup hal-hal sebagai berikut; (1) Harus serasi dengan pembinaan politik dan kesatuan bangsa; (2) Harus dapat menjamin hubungan yang serasi antara pemerintah pusat dan pemerintah daerah atas dasar keutuhan negara kesatuan; (3) Harus dapat menjamin perkembangan dan pembangunan daerah termasuk prinsipprinsip pembagian sumber-sumber keuangan yang adil; (4) Mampu memberdayakan dan meningkatkan kemampua perekonomian daerah; (5) Dapat menciptakan sistem pembiayaan daerah yang adil, proporsional, rasional, transparan, partisipatif, bertanggungjawab (akuntabel) dan pasti; dan (6) Semakin mempertegas sistem pertanggungjawaban keuangan oleh Pemerintah Daerah. 
Menurut Devas et al dikutip dalam Munir, Djuanda, Tangkilisan (2004: 7) pengelolaan keuangan daerah berarti mengurus dan mengatur keuangan daerah itu sendiri berdasarkan pada prinsip-prinsip:

1. Tanggung jawab,

2. Mampu memenuhi kewajiban keuangan,

3. Kejujuran,

4. Hasil guna dan daya guna, dan

5. Pengendalian.

Melalui misi utama dan tujuan utama pengelolaan keuangan daerah di atas, terlihat bahwa pemerintah daerah harus mempertanggung jawabkan tugas keuangannya kepada lembaga atau orang yang berkepentingan yang sah, yang meliputi DPRD dan masyarakat. Selain itu efektivitas dan efisiensi dalam pengelolaan keuangan daerah juga harus dilaksanakan. Hal ini berarti dalam pengelolaan keuangan daerah harus dilaksanakan sedemikian rupa sehingga program dan kegiatan yang telah direncanakan dapat dilaksanakan untuk mencapai tujuan pemerintah daerah dengan biaya yang serendah-rendahnya dan dalam waktu yang secepat-cepatnya. Secara garis besar, manajemen keuangan daerah dapat dibagi menjadi dua bagian, yaitu manajemen penerimaan daerah dan manajemen pengeluaran daerah. Kedua komponen tersebut akan sangat menentukan kedudukan suatu pemerintah daerah dalam rangka melaksanakan otonomi daerah (Mardiasmo, 2002).

Selanjutnya Nizarwan

(2004:70) mengatakan kebijakan umum pengelolaan keuangan daerah hendaknya harus memperhatikan berbagai hal seperti:

1. Dalam mengalokasikan anggaran baik rutin maupun pembangunan senantiasa berpegang pada prinsipprinsip anggaran berimbang dan dinamis serta efisien dan efektif dalam meningkatkan produktivitas;

2. Anggaran rutin diarahkan untuk menunjang kelancaran tugas pemerintahan dan pembangunan;

3. Anggaran pembangunan diarahkan untuk meningkatkan sektor-sektor secara berkesinambungan dalam mendukung penyempurnaan maupun memperbaiki sarana dan prasarana yang dapat menunjang peningkatan pembangunan dan kemasyarakatan dengan memperhatikan skala prioritas.

Anggaran Pendapatan dan Belanja Daerah (APBD)

Sesuai Peraturan Pemerintah Nomor 105 Tahun 2000 tentang Pengelolaan dan pertanggungjawaban Keuangan Daerah, APBD adalah suatu rencana keuangan tahunan daerah yang ditetapkan 
berdasarkan Peraturan Daerah tentang APBD. Dengan demikian, pemungutan semua penerimaan daerah dalam rangka pelaksanaan desentralisasi bertujuan untuk memenuhi target yang ditetapkan dalam APBD. Semua pengeluaran daerah dan ikatan yang membebani daerah dalam rangka pelaksanaan desentralisasi dilakukan sesuai jumlah dan sasaran yang ditetapkan dalam APBD, sehingga APBD menjadi dasar bagi kegiatan pengendalian, pemeriksaan dan pengawasan keuangan daerah. APBD merupakan dasar pengelolaan keuangan daerah dalam tahun anggaran tertentu.

Menurut UU Nomor 32 Tahun 2004 tentang Pemerintahan Daerah sumber penerimaan daerah terdiri dari (1) Pendapatan Asli Daerah (PAD), (2) Dana Perimbangan dan (3) Lain-lain pendapatan daerah yang sah.

Sedangkan menurut UU Nomor 33 Tahun 2004 tentang Perimbangan Keuangan Antara Pemerintah Pusat dan Pemerintah Daerah dalam pasal 5 ayat (1) menyatakan bahwa penerimaan daerah dalam pelaksanaan desentralisasi terdiri atas pendapatan daerah dan pembiayaan. Selanjutnya ayat 2 menjelaskan bahwa pendapatan daerah sebagaimana dimaksud pada ayat 1 bersumber dari : (1)
Pendapatan Asli Daerah (PAD), (2) Dana Perimbangan dan (3) Lain-lain pendapatan. Mardiasmo dalam Munir, Djuanda, Tangkilisan (2004: 36) mengatakan bahwa salah satu aspek penting dari pemerintah daerah yang harus diatur secara hati-hati adalah masalah pengelolaan keuangan dan anggaran daerah. Anggaran daerah atau APBD merupakan instrumen kebijakan utama bagi pemerintah daerah, menduduki posisi sentral dalam upaya pengembangan kapabilitas dan efektivitas pemerintah daerah. Anggaran daerah seharusnya digunakan sebagai alat untuk menentukan besarnya pendapatan dan belanja, alat bantu pengambilan keputusan dan perencanaan pembangunan serta alat otoritas pengeluaran dimasa yang akan datang dan ukuran serta alat koordinasi bagi semua aktivitas pada berbagai unit kerja.

Menurut Surat Edaran Menteri Dalam Negeri RI Nomor 903/2477/SJ tanggal 5 Desember 2001 perihal Pedoman Umum Penyusunan dan Pelaksanaan APBD Tahun Anggaran 2002, bahwa penyusunan APBD harus mengacu pada norma dan prinsip anggaran sebagai berikut:

1. Transparansi dan Akuntabilitas Anggaran. Merupakan persyaratan utama untuk mewujudkan pemerintahan yang baik, bersih dan 
bertanggungjawab.

Sebagai

instrument evaluasi pencapaian kinerja dan tanggungjawab Pemerintah Daerah mensejahterakan masyarakat, maka APBD harus dapat menyajikan informasi yang jelas tentang tujuan, sasaran, hasil dan manfaat yang diperoleh masyarakat dari suatu kegiatan atau proyek yang dianggarkan yang meliputi:

a. Disiplin Anggaran. APBD harus disusun berorientasi pada kebutuhan masyarakat tanpa harus meninggalkan keseimbangan antara pembiayaan penyelenggaraan pemerintahan, pembangunan dan pelayanan masyarakat. Oleh karena itu penyusunan anggaran hendaknya dilakukan berlandaskan azas efisiensi, tepat guna, tepat waktu pelaksanaan dan penggunaannya dapat dipertanggung jawabkan.

b. Keadilan Anggaran. Pendapatan Daerah pada hakekatnya diperoleh melalui mekanisme pajak dan retribusi atau beban lainnya yang dipikul oleh segenap lapisan masyarakat. Untuk itu, Pemerintah Daerah wajib mengalokasikan pengunaannya secara adil dan merata agar dapat dinikmati oleh seluruh kelompok masyarakat tanpa diskriminasi dalam pemberian pelayanan.

c. Menurut Mardiasmo (2004) anggaran merupakan pernyataan mengenai estimasi kinerja yang hendak dicapai selama periode waktu tertentu yang dinyatakan dalam ukuran finansial dan berisi rencana kegiatan yang direpresentasikan dalam bentuk rencana perolehan pendapatan dan belanja dalam satuan moneter. Anggaran sektor publik merupakan instrumen akuntabilitas atas pengelolaan dana publik dan pelaksanaan program-program yang dibiayai dengan uang publik. Penganggaran sektor publik terkait dengan proses penentuan jumlah alokasi dana untuk tiap-tiap program dan aktifitas dalam satuan moneter.

2. Perhitungan Anggaran. Mengingat APBD merupakan salah satu alternatif yang dapat merangsang kesinambungan serta konsistensi pembangunan di daerah, maka model penyusunan perhitungan APBD akan sangat erat kaitannya dengan keberhasilan pelaksanaan anggaran. Untuk itu sistem, prosedur, format dan 
struktur APBD yang selama ini digunakan, sangat tidak mampu mendukung tuntutan perubahan, dengan demikian perlu suatu perencanaan APBD yang lebih sistematis, terstruktur dan komprehensif (Mardiasmo, 2001: 5).

Produk Domestik Regional Brutto (PDRB)

Produk Domestik Regional Brutto (PDRB) merupakan salah satu indikator pertumbuhan ekonomi suatu Negara/wilayah/daerah. Pertumbuhan tersebut dapat dipengaruhi oleh beberapa faktor diantaranya infrastruktur ekonomi.

\section{Pendapatan Regional}

Pendapatan Regional merupakan pendapatan penduduk yang masuk dan keluar dapat dicatat dengan pendapatan netto antar wilayah/daerah didapatkan pendapatan regional (Produk regional Brutto). Karena sulitnya memperoleh data pendapatan masuk dan keluar suatu wilayah maka PDRN (Produk Domestik Regional Netto atas Dasar Biaya Faktor) diasumsikan sama dengan pendapatan regional atau pendapatan netto.

\section{Elastisitas}

Salah satu pokok bahasan yang amat penting dalam aplikasi teori ekonomi adalah konsep elastisitas. Pemahaman tentang elastisitas harga dari permintaan dan penawaran sangat membantu para pemerhati ekonomi dalam menjawab berbagai persoalan-persoalan harga jika permintaan dan penawaran mengalami perubahan.

Ditinjau dari segi bentuknya elastisitas dapat dibagi menjadi tiga yakni :

1. elastis,

2. unitary, dan

3. inelastis.

Dikatakan elastis jika perubahan harga terhadap permintaan bersifat positif. Dikatakan unitary jika perubahan harga terhadap permintaan sama dengan nol Dikatakan inelastis jika perubahan harga terhadap permintaan bersifat negatif.

\section{Kajian Penelitian Terdahulu}

Dalam penelitian yang dilakukan oleh Hasbulah (2006: 9) yang berjudul Analisis Kemampuan Keuangan Daerah Kota Mataram. Adapun variabel-variabel yang diamati dalam penelitian tersebut meliputi: Pendapatan Daerah, Belanja Daerah, Total Pendapatan Daerah (TPD), Bagi Hasil Pendapatan Bukan Pajak (BHPBP), APBD dan PDRB. Dari hasil kajiannya disimpulkan bahwa proporsi PAD terhadap Total Pendapatan Daerah (TPD) sebesar 7,87 persen, proporsi PAD ditambah BHPBP terhadap TPD sebesar 20,68 persen, rasio PAD terhadap belanja aparatur sebesar 14,16 persen, rasio PAD ditambah BHPBP terhadap belanja 
aparatur sebesar 37,19 persen. Akan tetapi jika diamati perkembangannya dari tahun ke tahun nampak bahwa proporsi PAD ini semakin menurun. Kondisi ini menunjukkan bahwa ketergantungan pemerintah daerah terhadap pemerintah pusat semakin besar. Ketergantungan yang semakin besar ini antara lain disebabkan oleh kondisi umum yang terjadi di semua kabupaten/kota yang diakibatkan oleh perubahan struktur anggaran seperti: gaji guru SD yang masuk dalam APBD, kenaikan gaji Pegawai Negeri Sipil (PNS). Keadaan ini akan mengakibatkan bertambahnya total APBD yang sumber penerimaannya berasal dari dana sumbangan pemerintah pusat.

Selanjutnya dikatakan bahwa Derajat Desentralisasi kota Mataram yang diukur melalui indeks standar kebutuhan fiskal (SKF) sebesar 4 kali lebih besar dari ratarata standar kebutuhan fiskal Provinsi Nusa Tenggara Barat. Kapasitas Fiskal (KF) Kota Mataram sebesar 4,8 kali bila dibandingkan dengan rata-rata kapasitas fiskal Nusa Tenggara Barat. Namun apabila terdapat selisih atau kekurangan, maka selisih tersebut diharapkan nantinya akan dapat ditutup melalui mekanisme dana transfer dari pemerintah pusat.

Dalam penelitiannya yang lain Hasbullah (2006: 6) yang berjudul Analisis Rasio Keuangan Pada Anggaran Pendapatan dan
Belanja Daerah Kabupaten Lombok Barat. Dimana variabel- variabel yang diamati dalam penelitian tersebut meliputi: Pendapatan Daerah, Belanja Aparatur Daerah, Belanja Pelayanan Publik, Biaya Pungutan PAD, Target Penerimaan PAD dan APBD. Dikatakan bahwa rasio kemandirian menggambarkan ketergantungan pemerintah daerah terhadap sumber dana dari luar (ekstern). Semakin tinggi rasio kemandirian mengandung arti bahwa tingkat ketergantungan pemerintah daerah terhadap bantuan pihak luar/ekstern (terutama pemerintah pusat/provinsi) semakin rendah, dan demikian pula sebaliknya. Rasio kemandirian juga menggambarkan tingkat partisipasi masyarakat dalam pembangunan daerah. Semakin tinggi rasio kemandirian, semakin tinggi pula partispasi masyarakat dalam membayar pajak dan retribusi daerah yang merupakan komponen utama pendapatan asli daerah (PAD). Semakin tinggi masyarakat membayar pajak dan retrebusi daerah akan dapat menggambarkan tingkat kesejahtraan masyarakat yang semakin tinggi pula. Berdasarkan hasil kajiannya sejak Tahun Anggaran 20022005 disimpulkan bahwa besarnya rasio kemandirian keuangan kabupaten Lombok Barat sebesar 8,70 persen, 6,65 persen, 
8,34 persen dan 8,09 persen. Ini berarti kemandirian daerah Kabupaten Lombok Barat dalam mencukupi kebutuhan pembiayaan untuk melakukan tugas

\section{Kerangka Konseptual}

\section{Gambar 1: Bagan Kerangka Pikir Penelitian}

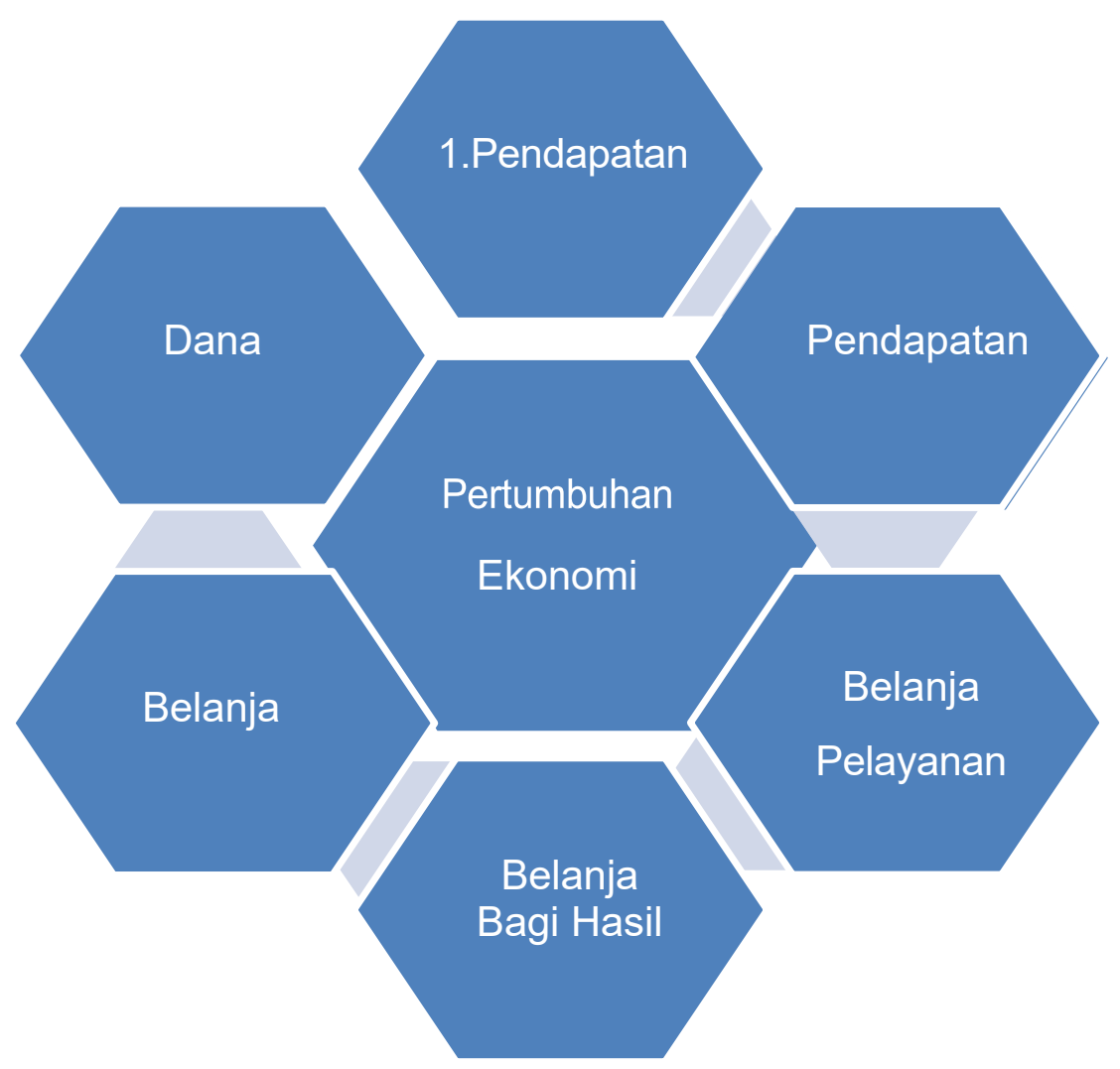

\section{METODE PENELITIAN}

\section{Jenis Penelitian}

Menurut tingkat eksplanasinya jenis penelitian ini termasuk penelitian deskriptif. Penelitian deskriptif adalah penelitian yang dilakukan untuk mengetahui nilai variabel mandiri, baik satu variabel atau lebih (independent) tanpa membuat perbandingan atau menghubungkan dengan variabel yang lain (Sugiyono, 1999:11). Selanjutnya menurut pemerintahan, pembangunan dan pelayanan masyarakat relatif masih rendah bahkan cendrung menurun. 
Barat, dipilihnya Kabupaten Lombok Timur secara purposive sampling dengan dasar pertimbangan bahwa Kabupaten Lombok Timur merupakan satu-satunya daerah terluas wilayahnya di pulauLombok dengan jumlah penduduk terbanyak, disamping terdapat pusat pendidikan, perdagangan yang cukup memadai.

\section{Teknik dan Alat Pengumpulan Data}

Data yang dikumpulkan dalam penelitian meliputi data APBD selama 4 (empat) tahun terakhir yang meliputi: Pendapatan Daerah, Pendpatan Asli Derah, Pendpatn Lain yang syah, PDRB dstnya selama kurun waktu Tahun 2016-2019 dengan cara :

1. Studi kepustakaan (Library Research), yaitu dengan cara mempelajari bukubuku, karangan ilmiah, jurnal ilmiah serta dokumen-dokumen lain yang berkaitan dengan analisis pertumbuhan PDRB dan elastisitas sesuai dengan judul penelitian.

2. Penelitian lapangan (Field Research), yaitu melakukan pengamatan secara langsung di lapangan terutama pada Biro Keuangan Sekretariat Daerah Kabupaten Lombok Timur Provinsi NTB sehubungan dengan data dan informasi terkait dengan variabelvariabel penelitian di atas.

Jenis dan Sumber Data
Penelitian ini menggunakan data skunder yaitu data yang dikumpulkan langsung dari Biro sekretariat Daerah Kabupaten Lombok Timur yang sudah dipublikasi sesuai data yang diperlukan dalam penelitian. Adapun data primer yang dimaksudkan terdiri dari: data APBD, Perubahan APBD, laporan perhitungan APBD, realisasi penerimaan daerah, realisasi belanja daerah, Nota Perhitungan APBD, Arus Kas dan Buku Perhitungan APBD Kabupaten Lombok Timur Provinsi NTB Tahun Anggaran 2016-2019.

Sedangkan data sekunder yang lainnya berupa data yang sudah dipublikasi yang terdiri dari: data PDRB, data demografis, perkembangan APBD, penerimaan dan belanja daerah, dan mekanisme penganggaran serta data-data Kabupaten Lombok Timur lainnya yang mendukung judul penelitian.

\section{Identifikasi dan Klasifikasi Variabel}

Dalam penelitian ini variabel yang diidentifikasi adalah sebagai berikut : (a) Pendapatan Daerah (PD), Pendapatan Asli Daerah (PAD), (c) Belanja Aparatur (BA), (d) Belanja Publik (BP) (e) Belanja Daerah (BD), (g). Anggaran Pendapatan dan Belanja Daerah (APBD), (h), Produk Domestik Regional Brutto (PDRB), (i) Produk Domestik regional Brutto Per Kapita (PDRB/Cap.) 


\section{Definisi Operasional Variabel}

Untuk menghindari penafsiran yang berbeda terhadap beberapa variabel yang digunakan dalam penelitian ini maka diberikan batasan-batasan sebagai berikut:

1. Pendapatan Asli Daerah (PAD) adalah pendapatan daerah yang diperoleh dari hasil pungutan pajak, retrebusi, hasil pengelolaan kekayaan daerah yang dipisahkan seperti BUMD dan lain-lain pungutan PAD yang syah berdasarkan Peraturan Daerah (PERDA) dan sesuai dengan peraturan perundang-undangan yang berlaku.

2. Pendapatan Daerah (PD) adalah semua penerimaan kas daerah dalam periode tahun anggaran tertentu yang menjadi hak daerah, tidak termasuk didalamnya unsur penerimaan UKP dalam kurun waktu tertentu (satu tahun)

3. Belanja Aparatur adalah semua pengeluaran kas daerah yang dipergunakan untuk mendanai administrasi penyelenggaraan pemerintahan daerah seperti: gaji Pegawai Negeri Sipil (PNS), Vakasi, lembur, pengadaan sarana dan parasarana birokrasi serta fasilitas lainnya termasuk pemeliharaan fasilitas inventaris yang sekaligus akan menjadi beban daerah dalam kurun waktu tertentu (satu tahun).

4. Belanja Publik adalah semua pengeluaran kas daerah yang dipergunakan untuk mendanai seluruh aktivitas pelayan publik seperti: pembangunan sarana pendidikan, sarana kesehatan, sarana perhubungan dan fasilitas umum lainnya yang dibutuhkan masyarakat sekaligus akan menjadi beban daerah dalam kurun waktu tertentu (satu tahun).

5. Belanja Daerah adalah adalah semua pengeluaran kas daerah dalam periode tahun anggaran tertentu yang menjadi beban daerah, terdiri dari belanja aparatur dan belanja pelayanan publik, tidak termasuk didalamnya unsur pengeluaran UKP.

6. Anggran Pendapatan dan Belanja Daerah (APBD) adalah rencana keuangan tahunan Pemerintah Daerah yang dibahas dan disetujuai bersama oleh Pemerintah Daerah dan Dewan Perwakilan Rakyat Daerah (DPRD) yang ditetapkan melalui Peraturan Daerah (PERDA).

7. Produk Domestik Regional Brutto (PDRB) adalah seluruh nilai produk barang dan jasa yang diproduksi di wilayah Kabupaten Lombok Timur 
tanpa memperhatikan apakah faktor produksinya berasal dari/atau dimiliki oleh penduduk Kabupaten Lombok Timur selama jangka waktu tertentu

\begin{tabular}{|c|c|c|}
\hline No. & $\begin{array}{c}\text { Besarnya Kontribusi } \\
\text { (\%) }\end{array}$ & Kriteria \\
\hline 1 & $76-100$ & Sangat besar \\
\hline 2 & $51-75$ & Besar \\
\hline 3 & $26-50$ & Cukup besar \\
\hline 4 & $0-25$ & Kurang besar \\
\hline
\end{tabular}

(satu tahun).

8. Produk Domestik Regional Brutto Per Kapita (PDRB/Cap.) adalah PDRB dibagi dengan jumlah penduduk pertengahan tahun yang berdomisili di Kabupaten Lombok Timur.

\section{Model Analisis Data}

\section{Analisis Pertumbuhan PAD Terhadap PDRB}

Guna mendapatkan gambaran tentang pertumbuhan PAD terhadap PDRB selama lima tahun terakhir (2006-2010) akan dianalisis dengan formulasi Widodo dalam Muin (2003: 36) sebagai berikut :

Xit - Xit - 1

$\Delta \mathrm{Xt}=\mathrm{x} 100 \%$

Xit -1

dimana:

$\Delta \mathrm{Xt}=$ Laju pertumbuhan PAD terhadap PDRB

$\Delta \mathrm{X} 1 \mathrm{t}=$ Laju pertumbuhan $\mathrm{PAD}$

$\Delta \mathrm{X} 2 \mathrm{t}=$ Laju pertumbuhan PDRB

$$
\begin{array}{ll}
\mathrm{t} & =\text { Tahun } \mathrm{txx} \\
\mathrm{t}-1 & =\text { Tahun Sebelumnya } \\
\mathrm{X} 1 & =\text { Variabel PAD } \\
\mathrm{X} 2 & =\text { Variabel PDRB }
\end{array}
$$

\section{Analisis Kontribusi PAD Terhadap PDRB}

Untuk mengetahui kontribusi PAD terhadap PDRB Kabupaten Lombok Timur akan dilakukan analisis dengan menggunakan rumus (G. Tan Melly, 1977) sebagai berikut:

$$
\text { A } \times 100 \%
$$

B

dimana :

$X=$ Persentase Kontribusi PAD terhadap PDRB Kabupaten Lombok Timur.

$A=$ Penerimaan PAD Kabupaten Lombok Timur periode tahun ke $n$.

$\mathrm{B}=$ PDRB Kabupaten Lombok Timur periode tahun ke $\mathrm{n}$.

Kriteria untuk menentukan besar kecilnya kontribusi Pendapatan Asli Daerah (PAD) terhadap Produk Domestik Regional Brutto (PDRB) Kabupaten Lombok Timur digunakan kriteria sebagai berikut (Soekartawi: 1995)

\section{Kriteria Kontribusi PAD terhadap PDRB}

\section{Analisis Elastisitas}

Adapun pendekatan elastisitas dimaksud adalah sebagai berikut :

$\triangle \mathrm{PAD}$

$\mathrm{E}=$ 
$\triangle$ PDRB

dimana :

$\mathrm{E}=$ Elastisitas dan

$\triangle P A D=$ Perubahan PAD

$\triangle \mathrm{PDRB}=$ Perubahan PDRB

\section{HASIL DAN PEMBAHASAN}

Perkembangan Kondisi Keuangan Daerah
Untuk mendapatkan gambaran tentang bagaimana Realisasi pendapatan daerah Kabupaten Lombok Timur sejak tahun 2016-2019 dengan seluruh komponen pendapatan daerah lainnya maka akan dapat dilihat dalam Anggaran Pendapatan dan Belanja Daerah Kabupaten Lombok Timur seperti yang disajikan dalam tabel di bawah ini.

Tabel IV.1: Anggaran Pendapatan dan Belanja Daerah (APBD) Kabupaten Lombok Timur Tahun 2016-2019 (jutaan rupiah)

\begin{tabular}{|c|l|c|c|c|c|}
\hline No. & \multicolumn{1}{|c|}{ U R A I A N } & Tahun 2016 & Tahun 2017 & Tahun 2018 & Tahun 2019 \\
\hline 1. & Pendatan Daerah & $1.715 .917 .407,3$ & $2.018 .726 .361,5$ & 2.374 .972 .190 & 2.596 .173 .283 \\
\hline 2. & Pend. Asli Daerah & 194.391 .179 & $228.695 .504,7$ & 269.053 .535 & 295.164 .950 \\
\hline 3. & Dana Perimbangan & $1.286 .363 .213,7$ & $1.513 .368 .486,7$ & 1.782 .786 .455 & 1.801 .638 .631 \\
\hline 4. & Lain2 Pend.Daerah & $23.463 .014,5$ & 274.662 .370 & 323.132 .200 & 499.369 .701 \\
\hline 5. & Belanja Daerah & $1.720 .424 .417,9$ & $2.024 .028 .726,9$ & 2.381 .210 .267 & 2.590 .628 .810 \\
\hline 6. & Bel. Tdk Langsung & $1.061 .465 .270,7$ & $1.248 .782 .671,4$ & 1.469 .156 .084 & 1.575 .583 .829 \\
\hline 7. & Belanja Langsung & $638.436 .527,4$ & $\mathbf{7 7 5 . 2 4 4 . 3 5 4 , 7}$ & 912.052 .182 & 1.015 .044 .981 \\
\hline \multicolumn{2}{|c|}{ J u m I a h } & $\mathbf{6 . 6 4 0 . 4 6 1 . 0 3 0 , 5}$ & $\mathbf{8 . 0 8 3 . 5 0 8 . 4 7 5 , 9}$ & $\mathbf{9 . 5 1 2 . 3 6 2 . 9 1 3 , 0}$ & $\mathbf{1 0 . 3 6 3 . 6 0 4 . 1 8 5 , 0}$ \\
\hline \multicolumn{2}{|c|}{ Rata-rata } & $\mathbf{9 4 8 . 6 3 7 . 2 9 0 , 1}$ & $\mathbf{1 . 1 5 4 . 7 8 6 . 9 2 5 , 1}$ & $\mathbf{1 . 3 5 8 . 9 0 8 . 9 8 7 , 5}$ & $\mathbf{1 . 4 8 0 . 5 1 4 . 8 8 3 , 5}$ \\
\hline
\end{tabular}

Sumber : Lombok Timur Dalam Angka Tahun 2016-2019

Dari data di atas dapat dijelaskan bahwa secara garis besarnya komponen pendapatan daerah dapat dikelompokkan kedalam Pendapatan Asli Daerah, Dana Perimbangan, Lain-lain Pendapatan Daerah Yang Sah. Sedangkan komponen Belanja Daerah terdiri dari Belanja Langsung dan Belanja Tidak Langsung. Dari seluruh komponen Pendapatan Daerah secara kuantitatif cenderung mengalami peningkatan sejak Tahun 2016-2019. Indikasi ini menunjukkan trend yang positif yang berarti pemerintah daerah
Kabupaten Lombok Timur secara berkesinambungan telah berhasil memenuhi target Penerimaan Daerah yang menjadi daya dorong dalam percepatan pencapaian Visi dan Misi di semua sektor kehidupan sesuai yang diamanhkan dalam Rencana Pembangunan Jangka Menengah Kabupaten Lombok Timur. Jika dilihat dari sisi Belanja Daerah, juga terus mengalami peningkatan secara cukup significan. Kondisi ini mengindikasikan bahwa pemerintah kabupaten Lombok Timur 
telah berupaya keras dalam merealisasikan program dan kegiatan yang tertuang dalam Rencana Program Jangka Menengh melalui realisasi Belanja Daerah yang setiap tahunnya semakin meningkat secara proforsional dengan Pendapatan Daerah yang diterimanya.
Untuk mendapatkan gambaran mengenai seberapa besar persentase kenaikan Anggaran Pendapatan dan Belanja Daerah Kabupaten Lombok Timur selama 4 (empat) tahun terakhir akan dapat ditujunjukkan melalui tabel di bawah.

Tabel IV.2: Persentase Perkembangan Anggaran Pendapatan dan Belanja Daerah (APBD)

Kabupaten Lombok Timur Tahun 2016-2019 (jutaan rupiah)

\begin{tabular}{|c|c|c|c|}
\hline No. & T A H U N & A P B D & $\begin{array}{c}\text { PERSENTASE } \\
\text { (\%) }\end{array}$ \\
\hline 1. & 2016 & $6.640 .461 .030,5$ & 22,71 \\
\hline 2. & 2017 & $8.083 .508 .475,9$ & 21,73 \\
\hline 3. & 2018 & $9.512 .362 .913,0$ & 17,67 \\
\hline 4. & 2019 & $10.363 .604 .185,0$ & 8,99 \\
\hline & J UM LAH & $\mathbf{3 4 . 5 9 9 . 9 3 6 . 6 0 4 , 4}$ & $\mathbf{7 1 , 1 0}$ \\
\hline & RATA-RATA & $\mathbf{8 . 6 4 9 . 9 8 4 . 1 5 1 , 1}$ & $\mathbf{1 7 , 7 7}$ \\
\hline
\end{tabular}

Sumber : Lombok Timur Dalam Angka Tahun 2016-2019.

Bersumber dari data di atas dapat ditunjukkan bahwa Anggaran Pendapatan dan Belanja Daerah (APBD) Kabupaten Lombok Timur selama 4 (empat) tahun terakhir cendrung mengalami penurunan yang cukup significan. Secara time series ditunjukkan bahwa pada Tahun 2016 peningkatan APBD naik sebesar $22,71 \%$, Tahun 2017 turun menjadi 21,73 \%, Tahun 2018 turun menjadi 17,67 \%, Tahun 2019turun lagi menjadi 8,99 \%. Secara keseluruhan total APBD selama 4 (empat) tahun terakhir berjumlah $\mathrm{Rp}$ 34.599.936.604,4 atau secara rata-rata sebesar Rp 8.649.984.151,1. Secara persentasi pencapaian APBD selama 4 (empat) tahun terakhir sebesar 71,10\% atau secara rata-rata per tahun sebesar $17,77 \%$. Penurunan penerimaan APBD di Kabupaten Lombok Timur ini tidak saja disebabkan oleh penurunan sumbersumber penerimaan, namun terlebih lagi diperparah oleh kondisi musibah global Covid-19 yang melanda dunia termasuk Kabuapetn Lombok Timur. Kondisi ini telah memperparah dan melumpuhkan kehidupan ekonomi secara total sehingga telah berdampak terhadap penerimaan dan Pendapatan Daerah secara significan. Selanjutnya jika kita ingin melihat lebih detail lagi berdasarkan sumber penerimaan daerah, maka akan kita temukan kondisi seperti yang tersaji dalam paparan di bawah ini. Dilihat dari 
komposisinya sebagian besar pendapatan daerah ini bersumber dari Dana alokasi Umum (DAU) dan Dana Alokasi Khusus (DAK). Pada tahun 2016 DAU yang diterima sebesar 1,16 Trilyun atau sekitar 52,29 persen dari total pendapatan daerah. Sedangkan pendapatan yang berasal dari Pendapatan Asli Daerah (PAD) tidak terlalu besar dilihat dari persentasinya terhadap total pendapatan. Tahun 2016 PAD Kabupaten Lombok Timur berjumlah 236 milyar atau sekitar 10,62 persen saja. Meskipun demikian jumlah PAD dari tahun ke tahun terus mengalami peningkatan. Jika dilihat dari segi penggunaan atau belanja daerah, total belanja daerah mencapai 2,23 trilyun pada tahun 2016 .

Dari komponen belanja daerah tersebut, belanja pegawai ternyata merupakan komponen yang paling besar. Sebagai ilustrasi jumlah belanja pegawai pada tahun 2016 mencapai 1,09 trilyun atau sekitar 48,89 persen dari total belanja daerah. Selanjutnya secara lebih komprehensif untuk melihat laju pertumbuhan Pendapatan Daerah Kabupaten Lombok Timur sejak tahun 2016-2019 akan disajikan pada tabel di bawah

Tabel IV.3: Pendapatan Daerah Kabupaten Lombok Timur

Tahun 2016-2019 (jutaan rupiah)

\begin{tabular}{|c|c|c|c|}
\hline Tahun & $\begin{array}{c}\text { Target } \\
\text { Anggaran }\end{array}$ & $\begin{array}{c}\text { Realisasi } \\
\text { Anggaran }\end{array}$ & $\begin{array}{c}\text { Pertumbuhannya } \\
\text { (\%) }\end{array}$ \\
\hline 2016 & $1.813 .108 .449,0$ & $1.715 .917 .407,3$ & 10,12 \\
\hline 2017 & $2.175 .546 .197,5$ & $2.018 .726 .361,5$ & 11,76 \\
\hline 2018 & $2.493 .364 .329,0$ & $2.374 .972 .190,0$ & 11,76 \\
\hline 2019 & $2.963 .364 .329,0$ & $2.596 .173 .283,0$ & 12,46 \\
\hline J u m I a h & $\mathbf{9 . 4 4 5 . 3 8 3 . 3 0 4 , 5}$ & $\mathbf{8 . 7 0 5 . 7 8 9 . 2 4 1 , 8}$ & $\mathbf{4 6 , 1 0}$ \\
\hline Rata-rata & $\mathbf{2 . 3 6 1 . 3 4 5 . 8 2 6 , 1}$ & $\mathbf{2 . 1 7 6 . 4 4 7 . 3 1 0 , 5}$ & $\mathbf{1 1 , 5 0}$ \\
\hline
\end{tabular}

Sumber: Kabupaten Lombok Timur dalam Angka 2016-2019, diolah.

Berdasarkan data tabel di atas dapat dijelaskan bahwa angka pertumbuhan pendapatan daerah dilihat dari realisasi anggaran tahun 2016 sebesar 10,12 persen, tahun 2017 sebesar 11,76 persen, tahun 2018 sebesar 11,76 persen, tahun 2019 sebesar 12,46 persen. Angka pertumbuhan tertinggi terjadi pada tahun 2019 yaitu sebesar 12,46 persen. Angka pertumbuhan rata-rata selama 4 (empat) tahun terhitung sejak tahun 2016-2019 mencapai 11,50 persen.

\section{Perkembangan Pendapatan Asli Daerah (PAD)}

Penjelasan berikutnya akan disajikan bagaimana pertumbuhan dan perkembangan pendapatan asli daerah Kabupaten Lombok Timur selama 5 (lima) 
tahun terakhir akan disajikan pada table di

bawah:

Tabel IV.4: Pendapatan Asli Daerah (PAD) Kabupaten Lombok Timur Tahun 2016-2019 (jutaan rupiah)

\begin{tabular}{|c|c|c|c|}
\hline Tahun & $\begin{array}{c}\text { Target } \\
\text { Anggaran }\end{array}$ & $\begin{array}{c}\text { Realisasi } \\
\text { Anggaran }\end{array}$ & $\begin{array}{c}\text { Pertumbuhannya } \\
\text { (\%) }\end{array}$ \\
\hline 2016 & $165.232 .503,0$ & $194.391 .179,0$ & 10,23 \\
\hline 2017 & $194.391 .179,0$ & $228.695 .504,7$ & 11,76 \\
\hline 2018 & $228.695 .505,7$ & $269.053 .535,0$ & 11,76 \\
\hline 2019 & $250.890 .207,5$ & $295.164 .950,0$ & 10,97 \\
\hline J u m I a h & $\mathbf{8 3 9 . 2 0 9 . 3 9 5 , 2}$ & $\mathbf{9 8 7 . 3 0 5 . 1 6 8 , 7}$ & $\mathbf{4 4 , 7 2}$ \\
\hline Rata-rata & $\mathbf{2 0 9 . 8 0 2 . 3 4 8 , 8}$ & $\mathbf{2 4 6 . 8 2 6 . 2 9 2 , 2}$ & $\mathbf{1 1 , 1 8}$ \\
\hline
\end{tabular}

Sumber: Kabupaten Lombok Timur dalam Angka 2016-2019, diolah.

Berdasarkan data tabel di atas dapat dijelaskan bahwa angka pertumbuhan pendapatan asli daerah (PAD) dilihat dari segi realisasi anggaran terhitung sejak tahun 2016 pertumbuhannya sebesar 10,23 persen, tahun 2017 naik menjadi sebesar 11,76 persen, tahun 2018 tetap Perkembangan Dana Perimbangan

Selama ini dana perimbangan baik yang bersumber dari Dana Alokasi Umum (DAU) maupun Dana Alokasi Khusus (DAK) telah menjadi faktor yang sangat menentukan dalam melengkapi kebutuhan anggaran pembangunan di Kabupaten Lombok Timur. Secara kuantitatif pertumbuhan dana perimbangan dimaksud setiap tahunnya terus mengalami peningkatan yang cukup significan. Dikarenakan pendapatan daerah yang belum mencukupi kebutuhan masyarakat Kabupaten lombok Timur dalam sebesar 11,76 persen dan tahun 2019 turun menjadi sebesar 10,97 persen. Angka pertumbuhan tertinggi terjadi pada tahun 2017 dan tahun 2018 yaitu sebesar 11,76 persen. Angka pertumbuhan ratarata selama 5 (lima) tahun terhitung sejak tahun 2016-2019 mencapai 11,18 persen. merealisasikan pembangunan di daerahnya, maka dana perimbangan yang bersumber dari pusat telah menjadi faktor yang sangat strategis guna merealisasikan program-program pembangunan masyarakat di daerah. Selanjutnya untuk melihat secara mendetail bagaimana peranan dana perimbangan dalam melengkapi kecukupan anggaran pembangunan di Kabupaten Lombok Timur akan dijelaskan melalui realisasi dan pertumbuhan dana perimbangan selama 4 (empat) tahun sejak tahun 2016-2019 akan disajikan pada tabel di bawah ini: 
Tabel IV.5: Perkembangan Dana Perimbangan Daerah Kabupaten Lombok Timur Tahun 2016-2019 (jutaan rupiah)

\begin{tabular}{|c|c|c|c|}
\hline Tahun & Target Anggaran & Realisasi Anggaran & rtumbuhannya (\%) \\
\hline 2016 & 1.021 .260 .000 & $1.286 .363 .213,7$ & 10,85 \\
\hline 2017 & 1.218 .269 .000 & $1.513 .368 .486,7$ & 11,76 \\
\hline 2018 & 1.307 .591 .000 & 1.782 .786 .455 & 11,78 \\
\hline 2019 & 1.243 .781 .000 & 1.801 .638 .631 & 10,10 \\
\hline J u m I a h & $\mathbf{6 . 5 3 1 . 3 2 9 . 0 0 0}$ & $\mathbf{6 . 3 8 4 . 1 5 6 . 7 8 6 , 4}$ & $\mathbf{4 4 , 4 9}$ \\
\hline Rata-rata & $\mathbf{1 . 3 0 6 . 2 6 5 . 0 0 0}$ & $\mathbf{1 . 5 9 6 . 0 3 9 . 1 9 6 , 6}$ & $\mathbf{1 1 , 1 2}$ \\
\hline
\end{tabular}

Sumber: Kabupaten Lombok Timur dalam Angka 2016-2019, diolah.

Berdasarkan data tabel di atas dapat dijelaskan bahwa angka pertumbuhan dana perimbangan yang bersumber dari Dana Alokasi Umum (DAU) dilihat dari segi realisasi anggaran terhitung sejak tahun 2016 pertumbuhannya sebesar 10,85 persen, tahun 2017 menjadi sebesar 11,76 persen, tahun 2018 menjadi sebesar 11,78 persen dan tahun 2019 menurun menjadi sebesar 10,10 persen. Angka pertumbuhan tertinggi terjadi pada tahun 2018 yaitu sebesar 11,78 persen. Angka pertumbuhan rata-rata selama 4 (empat) tahun terhitung sejak tahun 2016-2019 mencapai 11,12 persen.

\section{Perkembangan Kontribusi Dana \\ Perimbangan Terhadap PDRB (ADHB)}

PDRB atas dasar harga berlaku menggambarkan nilai tambah barang dan jasa yangdihitung menggunakan harga pada priode saat itu. Jadi PDRB tersebut dimaksudkan untuk menggambarkan bagaimana pertumbuhan ekonomi Kabupaten Lombok Timur selama priode pengamatan yang didasarkan pada harga riil barang dan jasa pada tahun pengamatan. Selanjutnya untuk melihat bagaimana peranan dan kontribusi Dana Perimbangan Terhadap PDRB Atas Dasar Harga Berlaku (ADHB) di Kabupaten Lombok Timur selama 4 (empat) tahun sejak tahun 20166-2019 akan disajikan pada tabel di bawah ini:

Tabel IV.6: Kontribusi Dana Perimbangan Terhadap Laju Pertumbuhan Ekonomi (PDRB)

Atas Dasar Harga Berlaku Kabupaten Lombok Timur Tahun 2016-2019 (jutaan rupiah).

\begin{tabular}{|c|c|c|c|}
\hline Tahun & Dana Perimbangan & $\begin{array}{c}\text { PDRB Atas Dasar Harga } \\
\text { Berlaku }\end{array}$ & $\begin{array}{c}\text { Persentase Kontribusi } \\
\text { (\%) }\end{array}$ \\
\hline 2016 & $1.286 .363 .213,7$ & $15.971 .050,90$ & 9,76 \\
\hline 2017 & $1.513 .368 .486,7$ & $17.549 .454,41$ & 10,98 \\
\hline 2018 & 1.782 .786 .455 & $18.828 .465,97$ & 10,73 \\
\hline 2019 & 1.801 .638 .631 & $20.305 .603,50$ & 10,78 \\
\hline Jumlah & $\mathbf{6 , 3 8 4 . 1 5 6 . 7 8 6 , 4 0}$ & $\mathbf{7 2 . 6 5 4 . 5 7 4 , 7 0}$ & $\mathbf{4 2 , 2 5}$ \\
\hline Rata-rata & $\mathbf{1 . 5 9 6 . 0 3 9 . 1 9 6 , 6 0}$ & $\mathbf{1 8 . 1 6 3 . 6 4 3 , 6 7}$ & $\mathbf{1 0 , 5 6}$ \\
\hline
\end{tabular}


Sumber: Kabupaten Lombok Timur dalam Angka 2016-2019, diolah.

Berdasarkan data tabel di atas dapat dijelaskan bahwa angka pertumbuhan Kontribusi Dana Perimbangan Terhadap Laju Pertumbuhan Ekonomi (PDRB) Atas Dasar Harga Berlaku Kabupaten Lombok Timur Tahun 2016-2019 sebagai berikut: terhitung sejak tahun 2016 pertumbuhan kontribusinya sebesar 9,76 persen, tahun 2017 meningkat menjadi sebesar 10,98 persen, tahun 2018 turun menjadi sebesar 10,73 persen, dan tahun 2019 menjadi 10,78 persen. Angka pertumbuhan tertinggi terjadi pada tahun 2017 yaitu sebesar 10,98 persen. Angka pertumbuhan rata-rata selama 4 (empat) tahun terhitung sejak tahun 2016-2019 mencapai 10,56 persen.

\section{Perkembangan Kontribusi Dana Perimbangan Terhadap PDRB (ADHK)} PDRB atas dasar harga konstan menggambarkan nilai tambah barang dan jasa yang dihitung dengan menggunakan harga yang berlaku pada priode tertentu (tahun 2010). Jadi PDRB tersebut dimaksudkan untuk menggambarkan bagaimana pertumbuhan ekonomi Kabupaten Lombok Timur selama priode pengamatan yang didasarkan pada harga tahun yang sudah ditentukan sebagai tahun perhitungan (tahun 2010). Selanjutnya untuk melihat bagaimana pertumbuhan Kontribusi Dana Perimbangan Terhadap PDRB Atas Dasar Harga Konstan Tahun 2010 (ADHK) Lombok Timur selama 4 (empat) tahun sejak tahun 2016-2019 akan disajikan pada tabel di bawah ini:

Tabel IV.7: Kontribusi Dana Perimbangan Terhadap Laju Pertumbuhan Ekonomi (PDRB) Atas Dasar Harga Konstan Tahun 2010 Kabupaten Lombok Timur Tahun 2012- 2016 (jutaan rupiah).

\begin{tabular}{|c|c|c|c|}
\hline Tahun & Dana Perimbangan & $\begin{array}{c}\text { PDRB Atas Dasar } \\
\text { Harga Konstan 10 }\end{array}$ & $\begin{array}{c}\text { Persentase } \\
\text { Kontribusi (\%) }\end{array}$ \\
\hline 2016 & $1.129 .526,0$ & 10.721 .723 & 10,53 \\
\hline 2017 & $1.243 .781,0$ & 11.249 .937 & 11,06 \\
\hline 2018 & $1.335 .017,0$ & 11.913 .551 & 11,21 \\
\hline 2019 & $1.749 .586,0$ & 12.535 .284 & 13,95 \\
\hline Jumlah & $\mathbf{5 . 4 5 7 . 9 1 0 , 0}$ & $\mathbf{4 6 . 4 2 0 . 4 9 5}$ & $\mathbf{4 6 , 7 5}$ \\
\hline Rata-rata & $\mathbf{1 . 3 6 4 . 4 7 7 , 0}$ & $\mathbf{1 1 . 6 0 5 . 1 2 3}$ & $\mathbf{1 1 , 6 8}$ \\
\hline
\end{tabular}

Sumber: Kabupaten Lombok Timur dalam Angka 2016-2019, diolah. 
Berdasarkan data tabel di atas dapat dijelaskan bahwa angka pertumbuhan Kontribusi Dana Perimbangan Terhadap Laju Pertumbuhan Ekonomi (PDRB) Atas Dasar Harga Konstan Kabupaten Lombok Timur Tahun 2016-2019 sebagai berikut: terhitung sejak tahun 2016 pertumbuhan kontribusinya sebesar 10,53 persen, tahun 2017 meningkat menjadi sebesar 11,06 persen, tahun 2018 meningkat menjadi sebesar 11,21 persen, tahun 2019 meningkat lagi menjadi sebesar 13,95 persen. Angka pertumbuhan tertinggi terjadi pada tahun 2019 yaitu sebesar 13,95 persen. Angka pertumbuhan ratarata selama 4 (empat) tahun terhitung sejak tahun 2016-2019 mencapai 11,68 persen.

\section{Perkembangan Pendapatan Lain Yang Sah}

Selain sumber-sumber pendapatan yang berasal dari Pendatan Asli Daerah (PAD) dan Dana Perimbangan, pemerintah daerah juga mempunyai peluang untuk mendapatkan sumber pendapatan yang berasal dari pendapatan lain yang syah seperti penyertaan modal pemerintah daerah dalam Badan Usaha Milik Daerah (BUMD) serta investasi lainnya yang bersifat produktif. Mengapa hal ini dapat diperkenankan karena jika pemerintah daerah hanya mengandalkan sumber pendapatannya dari sumber-sumber yang disebutkan di atas, akan sangat tidak mencukupi kebutuhan pembangunan dalam pelayanan masyarakat.

Dikarenakan kebutuhan pembangunan dan pelayanan masyarakat semakin lama semakin meningkat baik dalam bentuk kuantitas maupun kualitasnya.

Selanjutnya untuk melihat bagaimana realisasi dan pertumbuhan Pendapatan Lain Yang Syah selama 4 (empat) tahun sejak tahun 2016-2019 akan disajikan pada tabel di bawah ini:

Tabel IV.8: Perkembangan Pendapatan Lain Yang Syah di Kabupaten Lombok Timur Tahun 2016-2019 (jutaan rupiah)

\begin{tabular}{|c|c|c|c|c|}
\hline No. & Tahun & Target Anggaran & Realisasi Anggaran & $\begin{array}{c}\text { Pertumbuhanny } \\
\text { (\%) }\end{array}$ \\
\hline 1 & 2016 & 377.639 .300 & $235.463 .014,5$ & 12,50 \\
\hline 2 & 2017 & 851.152 .400 & $274.662 .370,0$ & 11,65 \\
\hline 3 & 2018 & 107.275 .480 & $323.132 .200,0$ & 11,78 \\
\hline 4 & 2019 & 118.287 .140 & $499.369 .701,0$ & 22,45 \\
\hline \multicolumn{2}{r|}{ J u m I a h } & $\mathbf{4 8 3 . 8 7 8 . 9 1 0}$ & $\mathbf{1 . 1 2 0 . 6 2 7 . 2 8 5 , 5}$ & $\mathbf{5 8 , 3 8}$ \\
\hline & Rata-rata & $\mathbf{9 6 7 . 7 5 , 7 8}$ & $\mathbf{2 8 0 . 1 5 6 . 8 2 1 , 3}$ & $\mathbf{1 4 , 5 0}$ \\
\hline
\end{tabular}

Sumber: Kabupaten Lombok Timur dalam Angka 2016-2019, diolah. 
Berdasarkan data tabel di atas dapat dijelaskan bahwa angka pertumbuhan Pendapatan Lain Yang Syah dilihat dari segi realisasi anggaran terhitung sejak tahun 2016 pertumbuhannya sebesar 12,50 persen, tahun 2017 meningkat menjadi sebesar 11,65 persen, tahun 2018 naik menjadi sebesar 11,78 persen dan tahun 2019 meningkat lagi menjadi 22,45 persen. Angka pertumbuhan tertinggi terjadi pada tahun 2019 yaitu sebesar 22,45 persen. Angka pertumbuhan rata-rata selama 4 (empat) tahun terhitung sejak tahun 20162019 mencapai 14,50 persen.

\section{Perkembangan Belanja Daerah}

Belanja daerah dalam suatu wilayah secara statistik cendrung terus mengalami peningkatan secara significan. Indikasi pertambahan belanja daerah ini merupakan salah satu indikator akan bertambahnya kebutuhan masyarakat baik yang disebabkan oleh perkembangan teknologi maupun yang diakibatkan oleh peristiwa demografi yaitu pertambahan jumlah penduduk maupun berdatangannya penduduk ke daerah perkotaan (in migration) baik untuk mencari pekerjaan maupun untuk menmpuh pendidikan. Kondisi ini membawa konsekuensi terhadap penambahan jumlah sarana dan prasarana yang dibutuhkan masyarakat tersebut. Faktor- faktor tersebut di atas sudah barang tentu harus dilayani oleh pemerintah daerah dalam bentuk penambahan belanja daerah guna memfasilitasi kebutuhan sarana dan prasarana masyarakat dalam wilayah Kabupaten Lombok Timur.

Selanjutnya untuk melihat bagaimana realisasi dan pertumbuhan Belanja Daerah selama 4 (empat) tahun sejak tahun 20162019 akan disajikan pada tabel di bawah ini:

Tabel IV.9: Perkembangan Belanja Daerah Kabupaten Lombok Timur Tahun 2016-2019

(jutaan rupiah)

\begin{tabular}{|c|c|c|c|}
\hline Tahun & $\begin{array}{c}\text { Target } \\
\text { Anggaran }\end{array}$ & $\begin{array}{c}\text { Realisasi } \\
\text { Anggaran }\end{array}$ & $\begin{array}{c}\text { Pertumbuhannya } \\
\text { (\%) }\end{array}$ \\
\hline 2016 & 1.160 .369 .000 & $1.720 .424 .417,9$ & 12,65 \\
\hline 2017 & 1.590 .493 .000 & $2.024 .028 .726,9$ & 11,76 \\
\hline 2018 & 1.807 .801 .000 & $2.381 .210 .267,0$ & 11,76 \\
\hline 2019 & 1.624 .283 .000 & $2.590 .628 .810,0$ & 10,87 \\
\hline J u m I a h & $\mathbf{8 . 3 9 8 . 6 7 5 . 0 0 0}$ & $\mathbf{8 . 7 1 6 . 2 9 2 . 2 2 1 , 8}$ & $\mathbf{4 7 , 0 4}$ \\
\hline Rata-rata & $\mathbf{1 . 6 7 9 . 7 3 5 . 0 0 0}$ & $\mathbf{2 . 1 7 9 . 0 7 3 . 0 5 5 , 5}$ & $\mathbf{1 1 , 7 6}$ \\
\hline
\end{tabular}

Sumber : Kabupaten Lombok Timur dalam Angka 20126-2019, diolah.

Berdasarkan data tabel di atas dapat dijelaskan bahwa angka pertumbuhan
Belanja Daerah dilihat dari segi realisasi anggaran terhitung sejak tahun 2016 
pertumbuhannya sebesar 12,65 persen, tahun 2017 menjadi sebesar 11,76 persen, tahun 2018 tetap sebesar 11,76 persen dan tahun 2019 menjadi sebesar 10,87 persen. Angka pertumbuhan tertinggi terjadi pada tahun 2017 dan tahun 2018 yaitu sebesar 11,76 persen. Angka pertumbuhan rata-rata selama 4 (empat) tahun terhitung sejak tahun 2016-2019 mencapai 11,76 persen.

\section{Perkembangan Belanja Tidak Langsung}

Perkembangan belanja daerah secara proforsional juga disebabkan oleh pertambahan kebutuhan masyarakat dalam pelayanan baik secara langsung maupun secara tidak langsung. Dalam kenyatannya belanja tidak langsung dapat juga berupa belanja pembangunan dan dapat pula dalam bentuk belanja proyek tergantung dari sekala prioritas yang tertuang Rencana Pembangunan Jangka Menengah (RPJM) daerah. Selanjutnya untuk melihat lebih jauh untuk apa dan seberapa besar kebutuhan belanja tidak langsung dan bagaimana realisasi dan pertumbuhannya di kabupaten lombok Timur selama 4 (empat) tahun sejak tahun 2016-2019 akan disajikan pada tabel di bawah ini:

Tabel IV.10: Perkembangan Belanja Tidak Langsung Kabupaten Lombok Timur Tahun 2016-2019 (jutaan rupiah)

\begin{tabular}{|c|c|c|c|}
\hline Tahun & Target Anggaran & Realisasi Anggaran & Pertumbuhannya (\%) \\
\hline 2016 & 1.149 .475 .000 & $1.061 .465 .270,7$ & 12,45 \\
\hline 2017 & 1.195 .012 .780 .000 & $1.248 .782 .671,4$ & 11,76 \\
\hline 2018 & 1.139 .538 .900 .000 & $1.469 .156 .084,0$ & 11,77 \\
\hline 2019 & 1.204 .500 .225 .000 & $1.575 .583 .829,0$ & 10,72 \\
\hline J u m I a h & $\mathbf{4 . 5 4 0 . 2 0 1 3 8 0 . 0 0 0}$ & $\mathbf{5 . 3 5 4 . 9 8 7 . 8 5 5 , 1}$ & $\mathbf{4 6 , 7 0}$ \\
\hline Rata-rata & $\mathbf{8 8 5 . 0 5 0 3 4 5 . 0 0 0}$ & $\mathbf{1 . 3 3 8 . 7 4 6 . 9 6 3 , 8}$ & $\mathbf{1 1 , 6 7}$ \\
\hline
\end{tabular}

Sumber : Kabupaten Lombok Timur dalam Angka 2016-2019, diolah.

Berdasarkan data tabel di atas dapat dijelaskan bahwa angka pertumbuhan Belanja Tidak Langsung dilihat dari segi realisasi anggaran terhitung sejak tahun 2016 pertumbuhannya sebesar 12,45 persen, tahun 2017 menjadi sebesar 11,76 persen, tahun 2018 menjadi sebesar 10,72 persen dan tahun tahun 2019 turun menjadi sebesar 10,72 persen. Angka pertumbuhan tertinggi terjadi pada tahun 2018 yaitu sebesar 11,7 persen. Angka pertumbuhan rata-rata selama 4 (empat) tahun terhitung sejak tahun 2016-2019 mencapai 11,67 persen.

\section{Perkembangan Belanja Langsung}

Dalam kenyatannya belanja langsung dapat juga berupa belanja rutin dalam bentuk gaji pegawai pemerintah daerah, 
belanja pembangunan dalam bentuk pembangunan sarana dan prasarana yang dibutuhkan masyarakat, dan dapat pula dalam bentuk belanja proyek atau pembangunan proyek-proyek strategis tergantung dari sekala prioritas yang tertuang Rencana Pembangunan Jangka Menengah (RPJM) daerah. Biasanya belanja langsung bahkan belanja pembangunan dimaksud hampir di semua daerah selalu didominasi oleh belanja rutin atau belanja pegawai. Hal ini dikarenakan oleh pembagian kewenangan antara pemerintah daerah kabupaten/kota seiirng dengan pelaksanaan otonomi daerah yang selama ini terjadi. Selanjutnya untuk melihat lebih jauh untuk apa dan seberapa besar kebutuhan belanja langsung dan bagaimana realisasi dan pertumbuhannya di kabupaten lombok Timur selama 4 (empat) tahun sejak tahun 2016-2019 akan disajikan pada tabel di bawah ini:

Tabel IV.11: Perkembangan Belanja Langsung di Kabupaten Lombok Timur Tahun 20162019 (jutaan rupiah)

\begin{tabular}{|c|c|c|c|}
\hline Tahun & Anggaran & Realisasi & $\begin{array}{c}\text { Pertumbuhannya } \\
\text { (\%) }\end{array}$ \\
\hline 2016 & $651.185 .779,0$ & $638.436 .527,4$ & 12,15 \\
\hline 2017 & $729.141 .378,0$ & $775.244 .354,7$ & 11,76 \\
\hline 2018 & $931.564 .278,0$ & $912.052 .182,0$ & 17,68 \\
\hline 2019 & $986.683 .562,0$ & $1.015 .044 .981,0$ & 11,12 \\
\hline J u m I a h & $\mathbf{3 . 2 9 8 . 5 7 4 . 9 9 7 , 0}$ & $\mathbf{3 . 3 4 0 . 7 7 8 . 0 4 5 , 1}$ & $\mathbf{5 2 , 7 1}$ \\
\hline Rata-rata & $\mathbf{8 2 4 . 6 4 3 . 7 4 9 , 0}$ & $\mathbf{8 3 5 . 1 9 4 . 5 1 1 , 2}$ & $\mathbf{1 3 , 1 7}$ \\
\hline
\end{tabular}

Sumber : Kabupaten Lombok Timur dalam Angka 2016-2019, diolah.

Berdasarkan data tabel di atas dapat dijelaskan bahwa angka pertumbuhan Belanja Langsung dilihat dari segi realisasi anggaran terhitung sejak tahun 2016 pertumbuhannya sebesar 12,15 persen, tahun 2017 meningkat menjadi sebesar 11,76 persen, tahun 2018 turun menjadi sebesar 17,68 persen dan tahun 2019 turun menjadi sebesar 11,12 persen. Angka pertumbuhan tertinggi terjadi pada tahun 2017 yaitu sebesar 17,68 persen.
Angka pertumbuhan rata-rata selama 4 (empat) tahun terhitung sejak tahun 20162019 mencapai 13,17 persen.

\section{Perkembangan Produk Domestik Regional} Bruto (PDRB)

Pendapatan Domestik Regional Brutto (PDRB) merupakan seluruh nilai tambah yang diciptakan dari berbagai aktivitas ekonomi di suatu daerah pada priode tertentu (satu tahun). Adapun dasar perhitungan PDB/PDRB sejak tahun 2016 
menggunakan tahun dasar 2010 dengan basis SNA 2008. Salah satu implikasi penggunaan SNA 2008 adalah perubahan nominal dan perubahan klasifikasi PDRB dari 9 sektor menjadi 17 katagori. PDRB atas dasar harga berlaku (ADH) Kabupaten Lombok Timur tahun 2016 mencapai 16,04 Trilyun rupiah.

Jika kita ingin melihat struktur ekonomi suatu daerah dapat dilihat dari kontribusi masing- masing katagori terhadap pembentukan PDRB. Angka PDRB Lombok Timur menunjukkan bahwa katagori pertanian, kehutanan, dan perikanan memiliki kontribusi terbesar dalam pembentukan PDRB. Sebagai gambaran pada tahun 2016 lebih dari 1/4 (seperempat) atau 28,35 persen PDRB
LombokTimur berasal dari katagori pertanian. Meskipun dari tahun ke tahun persentase ini semakin mengecil dengan pergerakan yang relatif 'kecil/halus'. Secara umum menunjukkan perlahan namun pasti kecendrungan usaha sektor pertanian semakin menurun/berkurang. Selain itu PDRB atas dasar harga konstan biasanya digunakan untuk melihat pertumbuhan ekonomi di suatu daerah. Dilihat dari segi laju pertumbuhan ekonomi Kabupaten Lombok Timur pada tahun 2016 mencapai 5,18 persen.

Selanjutnya untuk melihat bagaimana realisasi dan pertumbuhan PDRB (ADHK) dan (ADHB) Lombok Timur selama 4 (empat) tahun sejak tahun 2016-2019 akan disajikan pada tabel di bawah ini:

Tabel IV.12: Pertumbuhan Ekonomi (PDRB) Kabupaten Lombok Timur Tahun 2016-2019 (jutaan rupiah)

\begin{tabular}{|c|c|c|c|c|}
\hline No. & Tahun & $\begin{array}{c}\text { PDRB Atas Dasar } \\
\text { Harga Berlaku }\end{array}$ & $\begin{array}{c}\text { PDRB Atas Dasar } \\
\text { Harga Konstan 2010 }\end{array}$ & Pertumbuhan (\%) \\
\hline 1 & 2016 & $15.971 .050,90$ & $12.540 .497,50$ & 9,75 \\
\hline 2 & 2017 & $17.549 .454,41$ & $13.323 .964,53$ & 10,62 \\
\hline 3 & 2018 & $18.828 .465,97$ & $13.771 .632,88$ & 10,33 \\
\hline 4 & 2019 & $20.305 .603,50$ & $14.415 .564,75$ & 10,47 \\
\hline & J u m I a h & $\mathbf{7 2 . 6 5 4 . 5 7 4 , 7 0}$ & $\mathbf{5 4 . 0 5 1 , 6 5 9 , 5 0}$ & $\mathbf{4 1 , 1 7}$ \\
\hline & Rata-rata & $\mathbf{1 8 . 1 6 3 . 6 4 3 , 6 7}$ & $\mathbf{1 3 . 5 1 2 . 9 1 4 , 8 7}$ & $\mathbf{1 0 , 2 9}$ \\
\hline
\end{tabular}

Sumber: Kabupaten Lombok Timur dalam Angka 2012-2016, diolah.

Berdasarkan data tabel di atas dapat dijelaskan bahwa angka pertumbuhan Ekonomi (PDRB) dilihat dari segi PDRB Atas Dasar Harga Berlaku dan PDRB Atas Dasar Harga Konstan 2010 terhitung sejak tahun
2016 pertumbuhannya sebesar 9,75 persen, tahun 2017 meningkat menjadi sebesar 10,62 persen, tahun 2018 turun menjadi sebesar 10,33 persen, dan tahun 2019 meningkat menjadi sebesar 10,47 
persen. Angka pertumbuhan tertinggi terjadi pada tahun 2017 yaitu sebesar 10,62 persen. Angka pertumbuhan ratarata selama 4 (empat) tahun terhitung sejak tahun 2016-2019 mencapai 10,29 persen.
Selanjutnya jika kita ingin melihat distribusi Product Domestic Regional Brutto (PDRB) Atas Dasar Harga Berlaku diperuntukkan untuk jenis pengeluaran bidang apa saja yang paling menonjol, maka akan disajikan informasinya dalam tabel di bawah ini.

Tabel IV.13: Product Domestic Regional Brutto (PDRB) Atas Dasar Harga Berlaku Menurut Pengeluaran Kabupaten Lombok Timur Tahun 2016-2019 (dalam jutaan rupiah)

\begin{tabular}{|c|c|c|c|c|c|}
\hline No. & Jenis Pengeluaran & Tahun 2016 & Tahun 2017 & Tahun 2018 & Tahun 2019 \\
\hline 1. & Konsumsi rumah Tangga & $12.640 .425,6$ & $13.479 .947,23$ & $14.314 .969,55$ & $15.183 .158,80$ \\
\hline 2. & Konsumsi LNPRT & $457.517,5$ & $513.390,62$ & $594.437,20$ & $636.888,00$ \\
\hline 3. & Konsumsi Pemerintah & $2.713 .081,4$ & $2.915 .289,95$ & $3.004 .191,12$ & $3.074 .102,75$ \\
\hline 4. & Pembentukan Mod.Tetap & $5.982 .916,0$ & $6.466 .285,90$ & $6.883 .381,70$ & $7.584 .439,60$ \\
\hline 5. & Perubahan Inventori & $68.880,8$ & $78.226,56$ & $77.382,52$ & $76.986,49$ \\
\hline 6. & Net Expor Barang\&Jasa & $-5.891 .770,5$ & $-5.903 .685,85$ & $-6.045 .896,11$ & $-6.249 .972,14$ \\
\hline & P D R B & $\mathbf{1 5 . 9 7 1 . 0 5 0 , 9}$ & $\mathbf{1 7 . 5 4 9 . 4 5 4 , 4 1}$ & $\mathbf{1 8 . 8 2 8 . 4 6 5 , 9 7}$ & $\mathbf{2 0 . 3 0 5 . 6 0 3 , 5 0}$ \\
\hline
\end{tabular}

Sumber: Lombok Timur Dalam Angka Tahun 2016-2019

Berdasarkan data tabel di atas dapat dijelaskan bahwa dari sembilan jenis pengeluaran yang ada, ternyata peruntukan Product Domestic Regional Brutto (PDRB) berdasarkan harga berlaku terbesar diperuntukkan untuk jenis pengeluaran konsumsi rumah tangga, Pembentukan Mod.Tetap, Konsumsi Pemerintah, bahkan Net Expor Barang\&Jasa terus mengalami defisit selama empat tahun terakhir sampai dengan tahun 2019.

Jika kita ingin melihat distribusi Product Domestic Regional Brutto (PDRB) Atas Dasar Harga Konstan tahun 2010 diperuntukkan untuk jenis pengeluaran bidang apa saja yang paling menonjol, maka akan disajikan informasinya dalam tabel di bawah ini.

Tabel IV.14: Product Domestic Regional Brutto (PDRB) Atas Dasar Harga Konstan Tahun 2010 Menurut Jenis Pengeluaran Kabupaten Lombok Timur Tahun 2016-2019 (dalam jutaan rupiah)

\begin{tabular}{|c|c|c|c|c|c|}
\hline No. & Jenis Pengeluaran & Tahun 2016 & Tahun 2017 & Tahun 2018 & Tahun 2019 \\
\hline 1. & Konsumsi rumah Tangga & $9.859 .768,0$ & $10.117 .198,54$ & $10.369 .877,39$ & $10.694 .908,08$ \\
\hline 2. & Konsumsi LNPRT & $346.127,7$ & $372.784,00$ & $416.704,68$ & $434.909,15$ \\
\hline 3. & Konsumsi Pemerintah & $1.854 .053,5$ & $1.932 .825,42$ & $1.959 .206,27$ & $1.987 .494,60$ \\
\hline 4. & Pembentukan Mod.Tetap & $4.331 .167,3$ & $4.547 .225,31$ & $4.707 .642,69$ & $5.047 .038,53$ \\
\hline
\end{tabular}




\begin{tabular}{|l|c|c|c|c|c|}
\hline 5. & Perubahan Inventori & $8.342,7$ & $9.342,68$ & $8.999,04$ & $8.716,15$ \\
\hline 6. & Net Expor Barang\&Jasa & $-3.858 .961,7$ & $-3.655 .411,41$ & $-3.690 .797,18$ & $-3.757 .501,76$ \\
\hline & P D R B & $\mathbf{1 2 . 5 4 0 . 4 9 7 , 5}$ & $\mathbf{1 3 . 3 2 3 . 9 6 4 , 5 3}$ & $\mathbf{1 3 . 7 7 1 . 6 3 2 , 8 8}$ & $\mathbf{1 4 . 4 1 5 . 5 6 4 , 7 5}$ \\
\hline
\end{tabular}

Sumber: Lombok Timur Dalam Angka Tahun 2016-2019

Berdasarkan data tabel di atas dapat

dijelaskan bahwa dari sembilan jenis pengeluaran yang ada, ternyata peruntukan Product Domestic Regional Brutto (PDRB) berdasarkan harga konstan tahun 2010 terbesar masih diperuntukkan untuk jenis pengeluaran konsumsi rumah tangga baru diikuti dengan Pembentukan Mod.Tetap, Konsumsi Pemerintah, bahkan Net Expor Barang\&Jasa masih terus mengalami defisit selama empat tahun terakhir sampai dengan tahun 2019. Kendatipun demikian ternyata perkembangan Product Domestic Regional Brutto (PDRB) baik ditinjau dari harga berlaku maupun harga konstan 2010 terus mengalami peningkatan yang cukup signifikan.

Distribusi Laju Pertumbuhan PDRB Menurut Sektor Ekonomi

Jika kita ingin melihat Laju Pertumbuhan PDRB Menurut katagori atau Sektor Ekonomi, maka akan dapat kita amati dari berbagai katagori atau sektor ekonomi seperti yang disajikan pada tabel di bawah ini.

Tabel IV.15: Laju Pertumbuhan Product Domestic Regional Brutto (PDRB) Menurut Katagori Kabupaten Lombok Timur Tahun 2016-2019 (dalam persen)

\begin{tabular}{|c|c|c|c|c|c|}
\hline No. & Jenis Katagori & $\begin{array}{c}\text { Tahun } \\
2016\end{array}$ & $\begin{array}{c}\text { Tahun } \\
2017\end{array}$ & $\begin{array}{c}\text { Tahun } \\
2018\end{array}$ & $\begin{array}{c}\text { Tahun } \\
2019\end{array}$ \\
\hline 1. & Pertanian, Kehutanan dan Perikanan & 2,40 & 6,04 & 1,89 & 1,30 \\
\hline 2. & Pertambangan dan Penggalian & 9,28 & 7,17 & 5,87 & 10,52 \\
\hline 3. & Industri Pengolahan & 2,07 & 3,81 & 0,79 & 2,76 \\
\hline 4. & Pengadaan Listrik dan Gas & 9,84 & 4,51 & 1,01 & 9,28 \\
\hline 5. & Pengadaan Air,Peng.Sampah\&daur Ulang & 4,96 & 4,09 & $-4,65$ & 4,77 \\
\hline 6. & Konstruksi & 9,13 & 6,81 & 1,81 & 8,15 \\
\hline 7. & Perdag.Besar\&Eceran dan Koperasi & 7,23 & 8,12 & 5,88 & 6,48 \\
\hline 8. & Transportasi \&Perdagangan & 3,40 & 4,54 & 2,91 & 6,49 \\
\hline 9. & Penyediaan akomodasi \&Makan minum & 7,40 & 6,56 & 5,71 & 5,48 \\
\hline 10. & Informasi \&Komunikasi & 8,81 & 8,43 & 5,38 & 4,10 \\
\hline 11. & Jasa Keuangan\&Asuransi & 13,49 & 10,50 & 5,81 & 1,21 \\
\hline 12. & Real estate & 6,63 & 6,92 & 4,97 & 4,58 \\
\hline 13. & Jasa Perusahaan & 7,22 & 5,57 & 4,91 & 4,75 \\
\hline 14. & AdmPemerintahan,Pertahanan\&jaminansosial & 2,40 & 2,46 & 0,83 & 3,13 \\
\hline 15. & Jasa Pendidikan & 4,96 & 5,91 & 5,72 & 5,91 \\
\hline 16. & Jasa Kesehatan \&Kegiatan social & 5,88 & 6,14 & 7,94 & 6,17 \\
\hline 17. & Jasa Lainnya & 6,47 & 6,67 & 4,84 & 5,16 \\
\hline & Pertumbuhan Ekonomi & 5,23 & 6,25 & 3,36 & 4,68 \\
\hline
\end{tabular}

Sumber: Lombok Timur Dalam Angka Tahun 2016-2019 
Berdasarkan data tabel di atas dapat dijelaskan bahwa dari tujuh belas jenis katagori atau sektor ekonomi yang ada, ternyata laju pertumbuhan ekonomi (PDRB) Kabupaten Lombok Timur terbesar disumbangkan oleh sektor pertambangan sebesar $10,52 \%$ yang diikuti oleh sektor pengadaan listrik dan gas sebesar 9,28\%, konstruksi sebesar 8,15\% dan terendah disumbangkan oleh jasa keuangan dan asuransi sebesar $1,21 \%$ dan sektor Pertanian, Kehutanan dan Perikanan sebesar $1,30 \%$. Yang menarik dalam data di atas yaitu makin meurunnya peran sektor Pertanian, Kehutanan dan Perikanan dalam menyumbangkan laju pertumbuhan ekonomi di Kabupaten Lombok Timur. Indikasi ini menunjukkan Selanjutnya jika kita melihat laju pertumbuhan ekonomi Kabupaten Lombok Timur sejak tahun 2016-2019 ternyata berfluktuasi sebesar $5,23 \%, 6,25 \%, 3,36 \%$ dan $4,68 \%$.

Tabel IV.16: Laju Perubahan Pendapatan Asli Daerah (PAD) terhadap Product Domestic Regional Brutto (PDRB) Atas Dasar Harga Berlaku (ADHB) Kabupaten Lombok Timur Tahun 2016-2019 (dalam jutaan)

\begin{tabular}{|c|c|c|c|c|c|}
\hline No. & T A H U N & P A D & PDRB (ADHB) & $\Delta$ PAD & $\Delta$ PDRB \\
\hline 1. & 2016 & $194.391 .179,0$ & $15.971 .050,90$ & $29.158 .676,3$ & $1.341 .642,9$ \\
\hline 2. & 2017 & $228.695 .504,7$ & $17.549 .454,41$ & $34.304 .325,7$ & $1.578 .403,5$ \\
\hline 3. & 2018 & $269.053 .535,0$ & $18.828 .465,97$ & $40.358 .030,3$ & $1.279 .011,5$ \\
\hline 4. & 2019 & $295.164 .950,0$ & $20.305 .603,50$ & $26.111 .415,0$ & $1.477 .137,6$ \\
\hline \multicolumn{2}{r|}{ JUMLAH } & $\mathbf{9 8 7 . 3 0 5 . 1 6 8 , 7}$ & $\mathbf{7 2 . 6 5 4 . 5 7 4 , 7 0}$ & $\mathbf{1 2 9 . 9 3 2 . 4 4 7 , 3}$ & $\mathbf{5 . 6 7 6 . 1 7 7 , 5}$ \\
\hline \multicolumn{2}{r|}{ RERATA } & $\mathbf{2 4 6 . 8 2 6 . 2 9 2 , 2}$ & $\mathbf{1 8 . 1 6 3 . 6 4 3 , 6 7}$ & $\mathbf{3 2 . 4 8 3 . 1 1 1 , 8}$ & $\mathbf{1 . 4 1 9 . 0 4 4 , 4}$ \\
\hline
\end{tabular}

Sumber: Lombok Timur Dalam Angka Tahun 2016-2019

\section{Elastisitas PAD Terhadap PDRB}

Dalam ilmu ekonomi elastisitas merupakan perbandingan perubahan proforsional dari sebuah variabel dengan perubahan variabel lainnya atau dengan kata lain elastisitas mengukur seberapa besar kepekaan atau reaksi konsumen terhadap perubahan harga. Secara simbolik teoritis elastisitas dimaksud dapat digolongkan menjadi E > 1(elastis), E < 1 (In elastis) dan $E=1$ (unitary elastis). Selanjutnya untk melihat tingkat kepekaan dimaksud dapat didekati dengan 2 (dua) cara, yaitu berdasarkan atas dasar harga berlaku dan atas dasar harga konstasn. Untuk melihat kepekaan Pendapatan Asli Daerah terhadap Product Domestic Regional Brutto, maka terlebih dahulu akan dilihat perubahan masing-masing variabel dimaksud melalui penyajian tabel dibawah ini. 
Berdasarkan data tabel di atas dapat dijelaskan bahwa Laju Perubahan Pendapatan Asli Daerah (PAD) terhadap Product Domestic Regional Brutto (PDRB) Atas Dasar Harga Berlaku (ADHB) Kabupaten Lombok Timur Tahun 20162019 menunjukkan perubahan angka yang cukup significan atau menunjukkan angka yang terus mengalami peningkatan. Peningkatan tertinggi terjadi pada tahun 2018 sedangka terendah terjadi pada tahun 2019. Jika dilihat secara total selama empat tahun terakhir angka peningkatan
PAD sebesar Rp 129.932.447,3atau jika dilihat secara rata-rata maka peningkatan PAD terhadap PDRB berdasarkan harga berlaku setiap tahunnya sebesar $\mathrm{Rp}$ $32.483 .111,80$

Selanjutnya untuk melihat tingkat kepekaan Pendapatan Asli Daerah terhadap Product Domestic Regional Brutto atas dasar harga konstan (ADHK), maka terlebih dahulu akan dilihat perubahan masing-masing variabel dimaksud melalui penyajian tabel dibawah ini.

Tabel IV.17: Laju Perubahan Pendapatan Asli Daerah (PAD) terhadap Product Domestic Regional Brutto (PDRB) Berdasarkan Harga Konstan Tahun 2010 (ADHK) Kabupaten Lombok Timur Tahun 2016-2019 (dalam persen)

\begin{tabular}{|c|c|c|c|c|c|}
\hline No. & T A H U N & P A D & PDRB (ADHK) & $\Delta$ PAD & $\Delta$ PDRB \\
\hline 1. & 2016 & $194.391 .179,0$ & 10.721 .723 & $29.158 .676,3$ & $448.981,9$ \\
\hline 2. & 2017 & $228.695 .504,7$ & 11.249 .937 & $34.304 .325,7$ & $528.214,0$ \\
\hline 3. & 2018 & $269.053 .535,0$ & 11.913 .551 & $40.358 .030,3$ & $663.614,0$ \\
\hline 4. & 2019 & $295.164 .950,0$ & 12.535 .284 & $26.111 .415,0$ & $621.733,0$ \\
\hline \multicolumn{2}{r|}{ JUMLAH } & $\mathbf{9 8 7 . 3 0 5 . 1 6 8 , 7}$ & $\mathbf{4 6 . 4 2 0 . 4 9 5}$ & $\mathbf{1 2 9 . 9 3 2 . 4 4 7 , 3}$ & $\mathbf{2 . 2 6 2 . 5 4 2 , 9}$ \\
\hline \multicolumn{2}{|r|}{ RERATA } & $\mathbf{2 4 6 . 8 2 6 . 2 9 2 , 2}$ & $\mathbf{1 1 . 6 0 5 . 1 2 3}$ & $\mathbf{3 2 . 4 8 3 . 1 1 1 , 8}$ & $\mathbf{5 6 5 . 6 3 5 , 7}$ \\
\hline
\end{tabular}

Sumber: Lombok Timur Dalam Angka Tahun 2016-2019

Berdasarkan data tabel di atas dapat dijelaskan bahwa Laju Perubahan Pendapatan Asli Daerah (PAD) terhadap Product Domestic Regional Brutto (PDRB) Atas Dasar Harga Konstan tahun 2010 (ADHK) Kabupaten Lombok Timur Tahun 2016-2019 menunjukkan perubahan angka yang cukup significan atau menunjukkan angka yang terus mengalami peningkatan. Peningkatan tertinggi terjadi pada tahun
2018 sedangkan terendah terjadi pada tahun 2019. Jika dilihat secara total selama empat tahun terakhir angka peningkatan PAD terhadap PDRB sebesar Rp 2.262.542,9 atau jika dilihat secara ratarata maka peningkatan PAD terhadap PDRB berdasarkan harga berlaku setiap tahunnya sebesar Rp 565.635,7

Selanjutnya untuk melihat besaran elastisitas PAD terhadap PDRB ditinjau 
Atas Dasar Harga Berlaku (ADHB), maka sajian data dimaksud akan dapat dilihat pada tabel di bawah ini.

Tabel IV.18: Elastisitas Pendapatan Asli Daerah (PAD) terhadap Product Domestic Regional Brutto (PDRB) Berdasarkan Harga Berlaku (ADHB) di Kabupaten Lombok Timur Tahun 2016-2019 (dalam persen)

\begin{tabular}{|c|c|c|c|c|}
\hline No. & T A H U N & $\boldsymbol{\Delta}$ P A D & $\Delta$ PDRB (ADHB) & $\begin{array}{c}\text { ELASTISTAS } \\
(\mathbf{\%})\end{array}$ \\
\hline 1. & 2016 & $29.158 .676,3$ & $1.341 .642,9$ & 4,59 \\
\hline 2. & 2017 & $34.304 .325,7$ & $1.578 .403,5$ & 4,60 \\
\hline 3. & 2018 & $40.358 .030,3$ & $1.279 .011,5$ & 3,17 \\
\hline 4. & 2019 & $26.111 .415,0$ & $1.477 .137,6$ & 5,66 \\
\hline \multicolumn{2}{r|}{ JUMLAH } & $\mathbf{1 2 9 . 9 3 2 . 4 4 7 , 3}$ & $\mathbf{5 . 6 7 6 . 1 7 7 , 5}$ & $\mathbf{1 8 , 0 2}$ \\
\hline & RERATA & $\mathbf{3 2 . 4 8 3 . 1 1 1 , 8}$ & $\mathbf{1 . 4 1 9 . 0 4 4 , 4}$ & $\mathbf{4 , 5 0}$ \\
\hline
\end{tabular}

Sumber: Lombok Timur Dalam Angka Tahun 2016-2019

Berdasarkan data tabel di atas dapat dijelaskan bahwa tingkat kepekaan atau elastisitas PAD terhadap PDRB di Kabupaten Lombok Timur sejak tahun 2016-2019 ditunjukkan dalam tabel di atas. Secara kuantitatif besaran elastistas tersebut setiap tahunnya cendrung mengalami perubahan. Sebagai contoh besaran elastisitas PAD terhadap PDRBi berdsarkan harga berlaku tahun 2016 sebesar 4,59\%, tahun 2017 sebesar 4,60\%, tahun 2018 sebesar 3,17\% dan tahun 2019 sebesar 5,66 \%. jika dilihat secara rata-rata Tabel IV.19: Elastisitas Pendapatan Asli Daerah (PAD) terhadap Product Domestic Regional Brutto (PDRB) Berdasarkan Harga Konstan tahun 2010 di Kabupaten Lombok Timur Tahun 2016-2019 (dalam persen)

\begin{tabular}{|c|c|c|c|c|}
\hline No. & T A H U N & $\Delta$ P A D & $\Delta$ PDRB (ADHK) & ELASTISTAS \\
\hline 1. & 2016 & $29.158 .676,3$ & $448.981,9$ & 1,54 \\
\hline 2. & 2017 & $34.304 .325,7$ & $528.214,0$ & 1,53 \\
\hline 3. & 2018 & $40.358 .030,3$ & $663.614,0$ & 1,64 \\
\hline
\end{tabular}




\begin{tabular}{|c|c|c|c|c|}
\hline 4. & 2019 & $26.111 .415,0$ & $621.733,0$ & 2,38 \\
\hline \multicolumn{2}{|c|}{ JUMLAH } & $\mathbf{1 2 9 . 9 3 2 . 4 4 7 , 3}$ & $\mathbf{2 . 2 6 2 . 5 4 2 , 9}$ & $\mathbf{7 , 0 9}$ \\
\hline & RERATA & $\mathbf{3 2 . 4 8 3 . 1 1 1 , 8}$ & $\mathbf{5 6 5 . 6 3 5 , 7}$ & $\mathbf{1 , 7 8}$ \\
\hline
\end{tabular}

Sumber: Lombok Timur Dalam Angka Tahun 2016-2019

Berdasarkan data tabel di atas dapat dijelaskan bahwa tingkat kepekaan atau elastisitas PAD terhadap PDRB di Kabupaten Lombok Timur sejak tahun 2016-2019 secara kuantitatif besaran elastistas tersebut setiap tahunnya cendrung mengalami perubahan. Sebagai contoh besaran elastisitas PAD terhadap PDRB berdasarkan harga berlaku tahun 2016 sebesar 1,54\%, tahun 2017 sebesar 1,53\%, tahun 2018 sebesar 1,64\% dan tahun 2019 sebesar 2,38 \%. jika dilihat secara rata-rata selama 4 (empat) tahun, maka besaran elastisitas PAD terhadap PDRB setiap tahunnya sebesar $1,78 \%$. Ini berararti jika pendapatan daerah meningkat satu persen, maka akan berimplikasi terhadap kenaikan PDRB sebesar $1,78 \%$ dari tahun sebelumnya.

\section{KESIMPULAN DAN SARAN}

\section{Kesimpulan}

1. Laju perkembangan Pendapatan Asli Daerah (PAD) terhadap Product Domestic Regional Brutto (PDRB) Atas Dasar Harga Berlaku (ADHB) Kabupaten Lombok Timur Tahun 20162019 sebagai berikut: Tahun 2016 pertumbuhannya sebesar 9,75 persen, tahun 2017 meningkat tipis menjadi sebesar 10,62 persen, tahun 2018 turun menjadi sebesar 10,33 persen, tahun 2019 menjadi sebesar 10,47 persen. Angka pertumbuhan tertinggi terjadi pada tahun 2017 yaitu sebesar 10,62 persen. Angka pertumbuhan rata-rata selama 4 (empat) tahun terhitung sejak tahun 2016-2019 mencapai 10,29 persen.

2. Laju perkembangan Pendapatan Asli Daerah (PAD) terhadap Product Domestic Regional Brutto (PDRB) Atas Dasar Harga Konstan Tahun 2010 di Kabupaten Lombok Timur Tahun 20162019 sebagai berikut: Tahun 2016 pertumbuhan kontribusinya sebesar 10,04 persen, tahun 2017 meningkat menjadi sebesar 10,53 persen, tahun 2018 meningkat menjadi sebesar 11,06 persen, tahun 2019 meningkat lagi menjadi sebesar 11,21 persen. Angka pertumbuhan tertinggi terjadi pada tahun 2019 yaitu sebesar 13,95 persen. Angka pertumbuhan rata-rata selama 4 (empat) tahun terhitung sejak tahun 2016-2019 mencapai 11,36 persen.

3. Kontribusi dana perimbangan terhadap pendapatan daerah Kabupaten Lombok Timur sangat berpengaruh 
sehingga dampaknya terhadap laju pertumbuhan ekonomi yang dicerminkan dalam pertumbuhan PDRB (ADHB) maupun ADHK Kabupaten Lombok Timur selama 4 (empat) Tahun (2016-2019) relatif sangat signifikan.

4. Elastisitas PAD terhadap PDRB baik Atas Dasar Harga Berlaku maupun Atas Dasar Harga Konstan tahun 2010 secara rata-rata selama 4 (empat) tahun terakhir menunjukkan tren yang posisif atau Elastis. Artinya bahwa jika PAD naik satu satuan (\%), maka PDRB akan mengalami kenaikan lebih dari satu satuan (\%).

\section{Saran}

1. Mengingat besarnya peranan dana perimbangan baik yang bersumber dari dana alokasi umum (DAU) maupun yang bersumber dari dana alokasi khusus (DAK) terhadap pendapatan daerah dan pertumbuhan ekonomi (PDRB), maka pemerintah kabupaten Lombok Timur kedepannya tidak dapat secara terus menerus menggantungkan sumber pendapatan daerahnya dari dana perimbangan tersebut. Oleh karenanya mulai saat ini hendaknya pemerintah daerah harus sudah mulai berpikir tentang penggalian potensi sumber-sumber pendanaan dan pendapatan daerah lainnya agar tidak terlalu mengandalkan dana perimbangan sebagai sumber dana satu-satunya untuk melaksanakan pembangunan di berbagai sektor ekonomi.

2. Disamping optimalisasi penggalian potensi sumber dana, pemerintah kabupaten Lombok Timur hendaknya dapat melakukan intensifikasi perpajakan melalui penerapan efektivitas dan efisiensi sistem perpajakan serta pemberian reward and fanishment terhadap petugas pajak yang ada. Dari segi ekstensifikasi penerimaan yaitu dengan melakukan pendataan ulang seluruh potensi pajak sebagai sumber penerimaan yang ada di kabupaten Lombok Timur sehingga kedepan perlahan namun pasti sumber-sumber pendapatan daerah dari sektor pajak dan pendapatan lain yang syah dapat dimaksimalkan sehingga ketergantungan terhadap dana perimbangan secara perlahan mulai dapat dikurangi sedikit demi sedikit. 


\section{DAFTAR PUSTAKA}

Anonim, 2000. "Pedoman Umum Penyusunan dan Pelaksanaan APBD Tahun Anggaran 2001". Surat Edaran Mendagri No. 903/2735/SJ. 2001. "Pedoman Umum Penyusunan dan Pelaksanaan APBD Tahun Anggaran 2002". Surat Edaran Mendagri No. 903/2477/SJ. 2003. "Undang-Undang Republik Indonesia Nomor 17 tentang Keuangan Negara". Departemen Keuangan, Jakarta. , 2004. "Undang-Undang Nomor 32 tentang Pemerintah Daerah". Penerbit CV. Tamita Utama, Jakarta.

2004. "Undang-Undang Republik Indonesia Nomor 33 tentang Perimbangan Keuangan antara Pemerintah Pusat dan Daerah". Penerbit CV. Tamita Utama, Jakarta.

2005. "Peraturan Pemerintah Nomor 58 tentang Pengelolaan Keuangan Daerah".

Ditjen BAKD Depdagri, Jakarta.

2006. Permendagri Nomor : 13 tahun 2006 tentang Pedoman Pengelolaan Keuangan

Daerah, Direktorat Jendral Bina Administrasi Keuangan Daerah Depdagri, Jakarta. 2007. Peraturan Pemerintah Nomor : 58 tahun 2007 tentang Pedoman Pengelolaan

Keuangan Daerah, Direktorat Jendral Bina Administrasi Keuangan Daerah Depdagri, Jakarta.

Bastian, Indra., 2001. "Manual Akuntansi Keuangan Pemerintah Daerah 2001". Penerbit BPFE, Yogyakarta.

Halim, Abdul., 2002. "Akuntansi Keuangan Daerah". Penerbit Salemba Empat, Jakarta.

2004. "Bunga Rampai Manajemen Keuangan Daerah". Penerbit UPP AMP YKPN, Yogyakarta.

Hariyadi, Jasagung, 1999, "Evaluasi Sisa Perhitungan Anggaran Pada Perhitungan APBD Kabupaten Belitung Tahun Anggaran 1991/1992 - 2000", Tesis S-2, Program Pasca Sarjana Universitas Gadjah Mada, Yogyakarta (tidak dipublikasikan)

Hasbullah Yusuf, 2007, Anaisis Rasio Keuangan Pada Anggaran Pendapatan dan Belanja Daerah (APBD) Kabupaten Lombok Barat Tahun 2002-2005). Penerbit : Mataram Press Majalah Ilmiah ORIZA Universitas Mataram Vol.VI/No.2 April 2007.

2007, Analisis Kemampuan Keuangan Daerah Kota Mataram. Penerbit : Mataram Press Majalah IImiah ORIZA Universitas Mataram Vol.VI/No.3 Juli 2007.

Kama, 2002. "Evaluasi Akuntabilitas Kinerja Perencanaan APBD Tahun 2001 Bidang Pembangunan SDM di Lombok Tengah". Tesis S2, Program Pascasarja Magister Manajemen Fakultas Ekonomi Universitas Mataram (tidak dipublikasikan).

Kuncoro, Mudrajad., 2003. "Metode Riset Untuk Bisnis dan Ekonomi (Bagaimana meneliti \& menulis tesis)". Penerbit Erlangga, Jakarta.

Luo, Huaping and Robert T Golembiewski., 1996. "Budget Deficits in China Calculations, Causes, and Impacts". The Pennsylvania State University, JXR11 @ PSU.EDU.

Mamesah D.J., 1995. "Sistem Administrasi Keuangan Daerah". Penerbit PT. Gramedia Pustaka Utama, Jakarta.

Mardiasmo, MBA, Ak., 2000. Paradigma Baru Pengelolaan Keuangan Daerah Untuk Menyongsong Pelaksanaan Otonomi Daerah, Makalah Seminar HIMMEP, Yogyakarta. 
2001. "Perencanaan Keuangan Publik Sebagai Suatu Tuntutan Dalam Pelaksanaan Pemerintahan Daerah Yang Bersih dan Berwibawa". Makalah, Jakarta.

2002. "Otonomi dan Manajemen Keuangan Daerah". Serial Otonomi Daerah, Penerbit Andi Offset, Yogyakarta.

2004. "Akuntansi Sektor Publik". Penerbit Andi Offset, Yogyakarta.

Munir Dasril, Djuanda, Tangkilisan., 2004. "Kebijakan dan Manajemen Keuangan Daerah". Penerbit YPAPI, Yogyakarta.

Nazir Moh,Ph.D, 1983. Metode Penelitian, Penerbit: Ghalia Indonesia, Jakarta. Suparmoko.M,MA,Ph.D, 2003. Keuangan Negara dalam Teori dan Praktik, Edisi 5, Penerbit

BPFE, Yogyakarta

Sugiyono., 1999. “Metode Penelitian Bisnis”. Penerbit CV. ALFABETA, Bandung.

Wesen Eugene F. Brigham J. Fred., 2001. "Dasar-dasar Manajemen Keuangan". Edisi Kesembilan Jilid I.

Widodo, Hg, S.T., 1990. "Indikator Ekonomi Dasar Perhitungan Perekonomian Indonesia". Kanisius, Yogyakarta.

William, N Dunn., 1998. "Analisis Kebijakan Publik". Edisi Kedua, Gadjah Mada University Press, Yogyakarta. 